Rocio Riatto Della Coletta

\title{
ANÁLISE DAS REPETIÇÕES CA DO GENE IGF1, VNTR DO GENE DA INSULINA E REGIÃO PROMOTORA P4 DO GENE IGF2 EM INDIVÍDUOS NASCIDOS PEQUENOS PARA A IDADE
} GESTACIONAL

Tese apresentada à Faculdade de Medicina da Universidade de São Paulo para obtenção do título de Doutor em Ciências.

Área de concentração: Endocrinologia Orientadora: Dra Elaine Maria Frade Costa

São Paulo 
Dados Internacionais de Catalogação na Publicação (CIP)

Preparada pela Biblioteca da

Faculdade de Medicina da Universidade de São Paulo

Creprodução autorizada pelo autor

Della Coletta, Rocio Riatto

Análise das repetições CA do gene IGF1, VNTR do gene da insulina e região promotora P4 do gene IGF2 em indivíduos nascidos pequenos para idade gestacional / Rocio Riatto Della Coletta. -- São Paulo, 2008.

Tese(doutorado)--Faculdade de Medicina da Universidade de São Paulo.

Departamento de Clínica Médica.

Área de concentração: Endocrinologia.

Orientadora: Elaine Maria Frade Costa.

Descritores: 1.Recém-nascido pequeno para a idade gestacional 2.Retardo do crescimento fetal 3.Fator de crescimento insulin-like I 4.Fator de crescimento insulin-like II 5 .Insulina 6.Resistência à insulina

USP/FM/SBD-014/08 
Este trabalho foi realizado na Unidade de Endocrinologia do Desenvolvimento e no Laboratório de Hormônios e Genética Molecular LIM/42 da Disciplina de Endocrinologia do Hospital das Clínicas da Faculdade de Medicina da Universidade de São Paulo.

Apoio: FAPESP como bolsa de doutorado direto (processo 05/50093-9) e suporte parcial Projeto Temático (processo 05/04726-0). 


\section{Dedicatória}


Dedico esse trabalho aos meus avós (Luiz e Palmira D. Coletta; Leôncio e Lazarina Cunha - in memorian) e aos meus pais (Gilberto e Maria Silvéria D. Coletta) pelo exemplo de vida e coragem que sempre me impulsionaram aos novos desafios. 


\section{Agradecimentos}


É com certa ousadia e alegria que agradeço as inúmeras pessoas que contribuíram para que esse trabalho de doutorado se tornasse realidade.

Primeiramente, à Prof ${ }^{\text {a }}$ Dra Berenice B. Mendonça por ter-me incentivado e acreditado no meu potencial, incluindo-me no seu respeitável grupo de pesquisa.

À minha orientadora, Dra Elaine Maria Frade Costa por sua participação decisiva em cada passo do meu aprendizado, e pelas diversas fases da construção dessa tese. Obrigado pelo seu tempo, amizade, paciência, apoio e orientações que muito contribuíram para o meu crescimento científico e pessoal. Enfim, vencemos!!

Dr Paulo Pachi, Dr Carlos Longui, Dra Margaret Boguszewski e Ricardo Munhoz pelo incentivo e colaboração na casuística dessa tese.

Ao Alex, pesquisador admirável, amigo que muito opinou e contribuiu para que essa tese pudesse ser concluída.

À Emília pelo seu carinho e por sacrificar alguns de seus fins de semana para me dar seu gratificante apoio científico.

À amiga Ericka, com sua pronta e especial ajuda, foi para mim importante presença amparando-me nessa reta final; não tenho palavras que expressem minha gratidão.

À Milena, amiga querida e companheira de doutorado; o convívio contigo é sempre enriquecedor e motivante. Obrigado por existir!

Á Karina pelo seu especial apoio e amizade; e não poderia deixar de agradecer à Catarina, de quem sinto saudades, por sua mão amiga logo nos primeiros passos dessa tese.

Ao Madson e à Débora que foram amigos em "Real time", prontos e disponíveis!

À radiante Dra Ana Claúdia, pesquisadora cientificamente iluminada que nos inspira e motiva todos os dias.

Ao Dr Ivo, figura ímpar, que está sempre disposto a nos ajudar com suas sábias opiniões.

Ao Dr Sonir Antonini pelo apreço e pelas suas considerações de grande valia na aula de qualificação, moldando a conclusão dessa tese. 
À tia Dinah, Ana e Gina por estarem sempre disponíveis a me ajudar de forma solícita e alegre, e a você, Lúcia, pessoa maravilhosa, querida que sempre me auxiliou (lembra dos treinos das aulas?!), a vocês meu eterno agradecimento e carinho.

Ao Padre Joaquim pela sua carinhosa torcida, orações e sincera amizade.

Ao Bruno um privilégio poder contar com seu amor, incentivo e compreensão. Em muitos momentos tornou minha vida mais leve e feliz. Valeu Lindo!

À Erandy um anjo em minha vida que me acompanha e suaviza os momentos árduos da minha caminhada. Você muito contribuiu, com sua sabedoria, para que essa vitória fosse possível. Essa conquista também é sua, Obrigado!

Aos meus pais, junto a Deus, o dom da vida! Vocês muitas vezes priorizaram a vida das filhas (eu e a Déia) acima de suas próprias. Souberam me transmitir o valor da educação, do trabalho perseverante, do respeito ao próximo, que são valores que hoje norteiam minha essência. Embora a formação profissional de um médico seja praticamente interminável, se hoje cheguei até aqui, é porque vocês estiveram incondicionalmente ao meu lado dando-me sempre o equilíbrio emocional e, principalmente, me ensinaram a acreditar nos meus sonhos e nunca desistir diante dos obstáculos. Paizinho e mãezinha, a vocês eu não tenho palavras para agradecer, pois vocês são a melhor benção que Deus me deu! Essa é mais uma conquista que tenho a honra de comemorar com as pessoas que mais amo nesse mundo: vocês.

À minha querida Irmã, Déia, que sempre me apoiou em minhas escolhas. Obrigado pelo seu apoio e admiração recíproca que faz com que nossa amizade seja mais que especial. Te Amo.

Ao Fernando pelo carinho e atenção que me dedicou ao longo desses anos.

Aos meus diamantes: Bruna, Lucas (a caminho) e Pedro, saibam que o fato de existirem inspira-me um sorriso instantâneo na face e que em alguns momentos foram minha fonte de energia. 
O apoio financeiro da Fapesp: fundação de amparo á pesquisa do estado de São Paulo.

A todos (amigos, funcionários e familiares) que contribuíram direta ou indiretamente para que essa tese fosse concluída, o meu sincero agradecimento. Tenho certeza que independente de onde eu estiver vocês serão lembrados com carinho, pois vocês fizeram parte de uma fase que lembrarei num misto de superação e alegria por ter vencido essa importante etapa de minha vida profissional, e que muito contribuiu para meu crescimento pessoal e intelectual. Afinal, fazer um doutorado é uma experiência única, e que bom que fui divinamente abençoada por ter vocês como presença estimulante e agradável, dando a esse período de quatro anos toda leveza necessária para que essa tese fosse concluída com êxito. 
Sumário 


\section{SUMÁRIO}

Lista de abreviaturas

Lista de tabelas

Lista de figuras

Resumo

Summary

1. INTRODUÇÃO

1.1 Fisiologia do crescimento pré e pós-natal 2

1.2 Crianças nascidas pequenas para a idade gestacional 6

1.2.1 Definição 6

1.2.2 Morbidade e Mortalidade 7

1.2.2.a Associação entre nascer PIG e a baixa estatura na idade adulta 8

1.2.2.b Associação entre nascer PIG e o desenvolvimento de resistência insulínica e síndrome metabólica

1.2.2.c Associação entre nascer PIG e a presença de hipospádia 12

1.3 Modelos animais de retardo de crescimento intra-uterino 14

1.4 Genes envolvidos no crescimento pré e pós-natal em humanos

1.4.1 Polimorfismo $(\mathrm{CA})_{\mathrm{n}}$ da região promotora do gene IGF1

1.4.2 Polimorfismo VNTR do gene da insulina 19

1.4.3 Região promotora P4 do gene IGF2 23

2. OBJETIVOS 26

3. CASUÍSTICA E MÉTODOS 28

3.1 CASUÍSTICA 29

3.1.1 Grupo controle 31

3.1.2 Grupo de Estudo 31

3.2 MÉTODOS 31

3.2.1 Avaliação clínica 31

3.2.2 Avaliação bioquímica e hormonal 32 
3.2.3a Extração de DNA a partir de sangue periférico colhido em tubos com EDTA

3.2.3b Extração de DNA a partir de sangue periférico fixado em papel filtro

3.2.3c Análise do polimorfismo $(\mathrm{CA})_{n}$ do gene IGF1 pelo método do GeneScan

3.2.3d Análise do VNTR do gene da insulina (VNTR INS) utilizando digestão com enzima de restrição

3.2.3e Análise da região promotora P4 do gene IGF2 por seqüenciamento automático

3.2.3f Extração de RNAm de linfócitos

3.2.3g Análise da expressão gênica do IGF2 pela técnica de PCR em tempo real

3.2.4 Análise estatística

4. RESULTADOS

4.1 Avaliação Clínica e Laboratorial 45

4.2 Avaliação Molecular 47

4.2.1 Polimorfismo (CA $)_{n}$ do gene IGF1 47

4.2.2 Polimorfismo VNTR do gene da insulina 49

4.2.3 Região Promotora P4 do gene IGF2 50

5.DISCUSSÃO

5.1 Avaliação clínica $\quad 55$

5.2 Análise do polimorfismo CAn do gene IGF1 57

5.3 Análise do VNTR do gene da insulina 58

5.4 Análise da região promotora P4 do gene IGF2 58

6. CONCLUSÕES 61

7. ANEXOS 63

7.1 Anexo A - Protocolo de pesquisa $\quad 64$

7.2 Anexo B -Termo de consentimento livre e esclarecido $\quad 65$

7.3 Anexo C - Publicação 68

8.REFERÊNCIAS 
Abreviaturas 


\section{LISTA DE ABREVIATURAS}

\begin{tabular}{ll} 
AIG & Adequado para idade gestacional \\
ALS & Sub-unidade ácido-lábil \\
cm & Centímetro \\
DM2 & Diabetes melito tipo 2 \\
et al. & Autores colaboradores \\
g & Grama \\
GH & Hormônio do crescimento \\
GIG & Grande para idade gestacional \\
GTTO & Teste oral de tolerância à glicose \\
HOMA & Homeostasis Model Assessment \\
HOMA-IR & Índice para avaliar resistência insulínica \\
IGF1 & Insulin growth factor 1 \\
IGF1-R & Receptor do gene IGF1 \\
IGF2 & Insulin growth factor 2 \\
IGF2-R & Receptor do IGF2 \\
IGFBPs & Carreadores de fatores de crescimento \\
IGFs & Fatores de Crescimento \\
IMC & Índice de massa corpórea \\
INS & Insulina \\
INS-IGF2-TH & Cluster gênico:Insulina, IGF2 e Tirosina hidroxilase \\
INS-R & Receptor da insulina \\
\hline
\end{tabular}


IR

Insulino resistência

Kg Kilograma

$\mathrm{Pb}$

Pares de base

PIG Pequeno para idade gestacional

RCIU Restrição do crescimento intra-uterino

RA Receptor androgênico

RE Recuperação estatural

RNAm RNA mensageiro

SNC Sistema nervoso central

VNTR INS variable tanden repeat do gene da insulina 


\section{Tabelas}




\section{LISTA DE TABELAS}

Tabela 1: Porcentagem de redução do peso de camundongos knockout para os genes envolvidos no crescimento pré-natal

Tabela 2: Distribuição do grupo de estudo de acordo com os centros de origem

Tabela 3: Avaliação clínica dos indivíduos nascidos PIG

Tabela 4: Correlação das condições maternas na gestação com a presença de RE

Tabela 5: Distribuição dos alelos mais freqüentes das repetições CA do gene IGF1 nos indivíduos PIG e AIG (grupo controle)

Tabela 6: Distribuição Genotípica das Repetições CA do Gene IGF1 nos indivíduos PIG e AIG (grupo controle)

Tabela 7. Distribuição alélica do VNTR do gene da insulina entre os indivíduos PIG e AIG (grupo controle)

Tabela 8: Distribuição dos genótipos do VNTR do gene da insulina entre os indivíduos PIG e AIG (grupo controle)

Tabela 9: Distribuição alélica das variantes polimórficas $C_{n}$ encontradas na região P4 do gene IGF2 entre os indivíduos PIG e AIG (grupo controle)

Tabela 10: Distribuição dos genótipos das variantes $C_{n}$ encontradas na região P4 do gene IGF2 entre os indivíduos PIG e AIG (grupo controle) 
Fiquras 


\section{LISTA DE FIGURAS}

Figura 1: Ação dos hormônios envolvidos no crescimento pré e pós-natal.

Figura 2: Representação do gene IGF2 com exons (E), regiões promotoras $(P)$ e diferentes transcritos.

Figura 3 - Representação esquemática da digestão da região INS-23 A/T com enzima de restrição Hph1. Em indivíduos homozigoto A e homozigoto T, serão observados fragmentos de 40 pb, 129 pb e 191 pb e fragmentos de $129 \mathrm{pb}$ e $231 \mathrm{pb}$, respectivamente. Em indivíduos heterozigotos para o polimorfismo, todos os fragmentos, 40 pb, 129 pb, 191 pb e 231 pb, serão observados.

Figura 4: A) Polimorfismo 11C/11C-9C/T em homozigose; B) 10C/11C-9C/T em heterozigose na região promotora P4 do gene IGF2.

Figura 5: Heredograma de duas crianças que apresentaram a variação alélica $11 \mathrm{C}-9 \mathrm{C} / \mathrm{T}$. 
Resumo 


\section{RESUMO}

Coletta RRD. Análise das repetições CA do IGF1, VNTR do gene da insulina e região promotora P4 do gene IGF2 em indivíduos nascidos pequenos para idade gestacional [tese]. São Paulo: Faculdade de Medicina, Universidade de São Paulo; 2008.

Introdução: Polimorfismos na região promotora dos genes da insulina, IGF2 e IGF1 podem estar relacionados a uma diminuição da expressão desses genes na vida fetal que, por sua vez, pode causar restrição do crescimento intra-uterino e maior risco de hipospádia. Na vida pós-natal, perda completa ou parcial da expressão desses genes pode resultar em ausência de recuperação estatural e menores concentrações séricas de IGF1 na criança, além de um maior risco de diabetes melito tipo 2 e síndrome de resistência à insulina no adulto. Objetivos: Analisar em crianças nascidas pequenas para idade gestacional (PIG) com ou sem recuperação estatural (RE): 1) a freqüência alélica e genotípica dos polimorfismos VNTR-INS e das repetições CA do gene IGF1; 2) a região promotora P4 do gene IGF2; 3) a influência do VNTR INS e das repetições CA do gene IGF1 na sensibilidade à insulina e nas concentrações séricas de IGF1, respectivamente. Pacientes: Foram estudados 142 indivíduos nascidos PIG com ( $n=66)$ e sem recuperação $(n=76)$ estatural selecionados de três diferentes centros (HC-FMUSP, Santa Casa de São Paulo e HC-UFPR) e um grupo controle constituído de 297 indivíduos nascidos adequados para idade gestacional (AIG). Métodos: Extração de DNA genômico; amplificação por PCR das regiões contendo os polimorfismos VNTR INS e repetições CA do IGF1 e da região promotora P4; digestão por enzima de restrição; software Genescan; seqüenciamento automático; avaliação bioquímica e hormonal da glicemia, insulina e IGF1, extração de RNA, PCR em tempo real e análise estatística com SPSS 13.0 (Statistical Package fo Social Sciences). Resultados: A média do Z-altura, Z-IMC (índice de massa corpórea), Z-altura paterno e ZEA (estatura alvo) foram maiores nas crianças PIG que tiveram recuperação 
estatural, com o Z-PC (perímetro cefálico) maior nas crianças sem recuperação estatural. O Z-IGF1 sérico foi significantemente mais elevado em crianças que apresentaram $\operatorname{RE}(p<0,05)$. A distribuição e genotipica das repetições CA do gene IGF1 e do VNTR INS foi semelhante estatisticamente entre os grupos AIG e PIG, e entre os PIG com e sem RE; não foi observada associação entre esse polimorfismo e as variáveis clínicas e laboratoriais do estudo. O estudo da região promotora P4 do gene IGF2 identificou um novo polimorfismo de 9-12 repetições C na posição -1982, antes do sítio de início de transcrição do exon 2, e este apresentou distribuição semelhante entre os grupos PIG e AIG. Foi identificada também uma troca $\mathrm{C} / \mathrm{T}$ em heterozigose no nono nucleotídeo do alelo $11 \mathrm{C}$ em quatro crianças nascidas PIG. Contudo, a quantificação da expressão do gene IGF2 em duas dessas crianças não demonstrou perda da expressão desse gene. Conclusões: Não observamos influência dos polimorfismos acima descritos no crescimento pré e pós-natal, na presença de resistência à insulina, nem em concentrações séricas de IGF1 dos indivíduos nascidos PIG. Identificamos uma nova variante na região promotora P4 do gene IGF2, contudo estudos preliminares não demonstraram influência desse polimorfismo sobre o crescimento intra-uterino.

Descritores: 1) Recém-nascido pequeno para idade gestacional; 2) Retardo do crescimento fetal; 3) Fator de crescimento insulin-like I; 4) Fator de crescimento insulin-like II; 5) Insulina; 6) Resistência à insulina. 
Summary 


\section{SUMMARY}

Coletta RRD. Analysis of the CA repeats of IGF1 gene, VNTR of insulin gene polymorphism and P4 Promoter region of IGF2 gene in children born small for gestational age [Doctoral thesis]. Faculty of Medicine, University of Sao Paulo, SP (Brazil); 2008.

Introduction: Polymorphisms in the promoter region of insulin (INS), IGF2 and IGF1 genes may decrease their expression during fetal life and afterward could be related to intra-uterine fetal growth retardation and greater risk of hypospadia development. In post-natal life, decreased expression of these genes can result in lack of stature recovery and in lower IGF1 serum levels in children, as well as in higher risk for type 2 diabetes mellitus and metabolic syndrome in adults. Objectives: The aims of the present study were: (1) to analyze the allelic and the genotypic frequency of the insulin (INS) gene variable number of tandem repeats (VNTR) and the IGF1 gene CA repeats; (2) to analyze the P4 promoter region of IGF2 gene (3) to test the contribution of INS VNTR, IGF1 gene CA repeats on insulin sensitivity and IGF1 serum levels in children born SGA with and without catch up, respectively. Patients: We studied 142 individuals born SGA with catch up (n = 66) and without catch up $(n=76)$ selected from three different centers (HCFMUSP, Santa Casa de Sao Paulo and HC-UFPR). The control group consisted of 297 children born appropriate for gestational age (AGA). Methods: Extraction of genomic DNA, PCR-amplification of the VNTR of insulin gene, CA repeats of IGF1 and IGF2 gene P4 promoter region; restriction analysis; Genescan software; automatic sequencing. Blood measurements of serum level of glucose, insulin and IGF1. Statistical analysis (Statistical Package for Social Sciences software). Results: Regarding birth parameters, the average of Z-height, Z-BMI (body mass index) and Z-height paternal and Z- EA (target height) were higher in children born SGA who had catch up. Interestingly, we observed that the Z-PC was higher in children born SGA without catch up. In addition, the Z-IGF1 serum levels were significantly higher in children who had catch up $(p<0.05)$. The 
molecular analysis of IGF1 gene CA repeats and of INS gene VNTR locus did not show a statistically significant difference in the allelic and genotypic distribution of these polymorphisms between adequate for gestational age (AGA) and SGA groups nor between SGA with and without catch up. Similarly, we have not found an association of these polymorphisms with clinical or laboratory variables of this study. A novel polymorphism in the P4 promoter region of the IGF2 gene was identified. It was characterized by cytosine repeats (9-12) at position -1982 before transcription initiation site of exon 2 of IGF2 gene. Yet, we have identified a heterozygous substitution of cytosine for thymine at the nucleotide position 9 in the allele $11 \mathrm{C}$ in four children born SGA. This change was also absent in the control population. Quantization of IGF2 gene expression in two of these children did show loss of expression of this gene in patients carrying the variant $9 \mathrm{C} / \mathrm{T}$. Conclusions: We have not observed an association of the above described polymorphisms with pre and post natal growth, or with the occurrence of insulin resistance in individuals born SGA. IGF-1 levels did not seem to be associated with the polymorphisms either. A new variant in the $\mathrm{P} 4$ promoter region of IGF2 gene was identified, however preliminary studies showed no influence on intra-uterine growth.

Descriptors: 1) Infant, small for gestational age; 2) Fetal growth retardation; 3) Insulin-like growth factor I; 4) Insulin- like growth factor II; 5) Insulin; 6) Insulin resistance. 


\section{Introdução}


1.1 Fisiologia do crescimento pré e pós-natal

O crescimento pré-natal depende da complexa interação entre três sistemas distintos, os quais se encontram em íntima interação: mãe, placenta e feto. O crescimento e a diferenciação observados no concepto antes da implantação e no período embrionário inicial são relativamente independentes dos fatores ambientais (mãe e placenta), relacionando-se, principalmente, com fatores genéticos inerentes ao próprio embrião [1].

Em contraste, no último trimestre de gestação, quando a maior parte da organogênese já se completou, o crescimento fetal é acelerado e o ambiente intra-uterino passa a ser de fundamental importância para o crescimento e desenvolvimento normais [1]. A habilidade da unidade úteroplacentária em fornecer adequada quantidade de substratos, principalmente glicose, aminoácidos (aa), lactato, corpos cetônicos e oxigênio, é determinante para que o feto expresse adequadamente o seu potencial genético de crescimento.

Os principais fatores endócrinos determinantes para o crescimento fetal do início ao final da gestação são o IGF2, o IGF1 e a insulina [2], nessa ordem de importância. Em contrapartida, o GH (hormônio de crescimento) exerce pouco efeito nessa fase da vida [3].

O IGF2 é resultante da ação da enzima placentária convertase 4 , a qual transforma o peptídeo bioinativo pré-pro IGF2 em IGF2, sendo expresso de forma constitutiva no início da gestação [4]. Em conjunto com o IGF1, age no receptor tipo 1 de IGF (IGF1-R) e é fundamental para o crescimento embrionário inicial. 
Qiu et al. [4] observaram que gestantes de fetos PIG apresentavam altas concentrações de pré-pro IGF2 e concentrações mais baixas de IGF2, quando comparadas às gestantes de fetos $A I G$, o que sugere uma deficiência na síntese ou na ação da enzima convertase 4. Portanto, a dosagem de pré-pro IGF2 materna durante a gestação pode ser um útil marcador para se identificar os fetos que nascerão pequenos para a idade gestacional (PIG) [5].

Nos estágios mais avançados da gestação, quando a função placentária passa a ser um fator limitante para o crescimento fetal, o IGF1 assume o papel de principal regulador do crescimento [6]. Gluckman et al. [2] demonstraram que o tamanho do recém-nascido apresenta correlação direta com as concentrações de IGF1 no cordão umbilical que são diretamente influenciadas pelo estado nutricional do feto

O IGF1 presente na circulação e no fluido extracelular encontra-se ligado a uma família de proteínas transportadoras de alta afinidade, as IGFBPs (IGF-binding proteins) que regulam a disponibilidade dos IGFs para seus sítios de ligação no IGF1-R. Além disso, possuem funções independentes, podendo modular as ações dos IGFs produzidos nos diversos tecidos [7]. O fígado é o principal órgão responsável pela síntese do IGF1 encontrado na circulação sangüínea.

Atualmente, estão bem caracterizadas, do ponto de vista molecular e bioquímico, seis IGFBPs denominadas IGFBP-1 a IGFBP-6. A IGFBP-1 parece ser a mais importante proteína transportadora durante o período prénatal, pois recém-nascidos com RCIU (restrição do crescimento intra-uterino) 
possuem altas concentrações séricas de IGFBP-1, o que, provavelmente, diminui a quantidade de IGF1 disponível para promover o crescimento fetal. Além disso, a IGFBP-1 possui relação inversa com as concentrações de insulina fetal, embasando a importância da insulina no crescimento intrauterino $[8,9]$. Aproximadamente $80 \%$ do IGF1 circulante encontram-se sob a forma de um complexo ternário de $150 \mathrm{KDa}$, composto por uma molécula de IGF1, uma molécula de IGFBP-3 e uma molécula da sub-unidade ácido lábil (ALS), a qual prolonga a meia vida do IGF1 circulante; $20 \%$ encontram-se ligados a outras IGFBPs, e menos de 5\% encontram-se em forma livre [10].

As concentrações séricas de IGF1 oscilam durante a vida; ao nascimento, apresentam níveis baixos e correlacionam-se diretamente com a idade gestacional $[11,12]$. Sabe-se que as concentrações de IGF1 no recém-nascido são 30\% - 50\% dos níveis de um indivíduo adulto. Durante a infância, as concentrações séricas de IGF1 elevam-se, atingindo valores de adulto na pré-puberdade [13]. Na puberdade, os valores de IGF1 são duas a três vezes maiores que nos adultos, e após os 30 anos, tendem a diminuir gradativamente com a idade [14].

Diferentemente, as concentrações séricas de IGF2, ao nascimento, são $50 \%$ menores que no indivíduo adulto. Contudo, geralmente, os indivíduos atingem os valores de IGF2 do adulto com um ano de idade, e os mantém nessas concentrações por toda vida [15, 16].

Em relação às concentrações séricas de insulina, sabe-se que elas têm relação direta com o tamanho ao nascimento [17], sendo produzidas pelo feto desde o final do primeiro trimestre da gestação [18]. No início da 
puberdade, há um aumento fisiológico da insulina, chegando a elevar-se de 2 a 3 vezes com o pico de velocidade de crescimento, e tende a retornar ao normal após o estirão da puberdade em indivíduos sem fatores de risco para diabetes [19-23]. O aumento da insulina na puberdade está relacionado à maior secreção de GH nessa fase da vida [24].

A insulina também promove o crescimento fetal por seu efeito lipogênico, o qual independe do IGF1, provocando aumento do tecido adiposo fetal quando as concentrações de insulina são elevadas, como em fetos de mãe com diabetes descompensado [25]. Quando existe uma hiper secreção de insulina, a mesma atua como um fator de crescimento, ligandose e ativando os receptores IGF1-R [26]. Em contrapartida, a agenesia pancreática provoca importante retardo do crescimento fetal [27].

Em resumo, a regulação da secreção de IGF1 e do crescimento prénatal é realizada pelo eixo glicose-insulina-IGF1. A placenta transfere glicose para o feto, o que estimula a secreção de insulina fetal que, por sua vez, determina a secreção de IGF1 [28]. Enquanto no período pré-natal o hormônio de crescimento exerce pouca influência no crescimento fetal, na vida pós-natal ele passa a ser o principal regulador da expressão de IGF1, e o sistema GH/IGF-1 o principal determinante do crescimento linear (Figura 1). 


\section{Período pré-natal}

\section{Período pós-natal}

Transferência de nutrientes mãe - feto

\section{GH}

Início da gestação

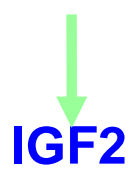

Final da gestação

IGF1 $\leftarrow$ INS-R

GHR

\section{Insulina}

IGF1

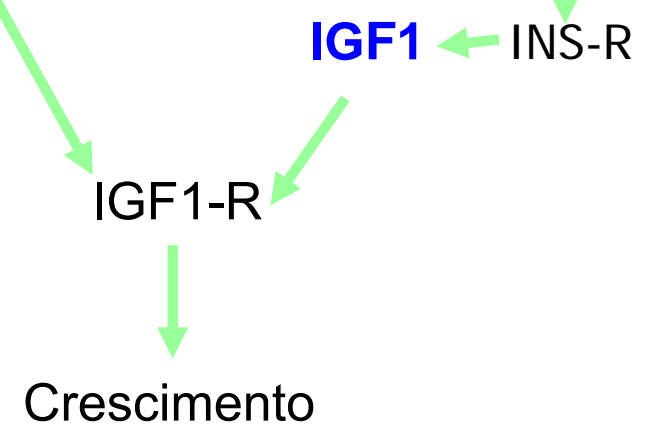

\section{Crescimento}

Figura 1: Ação dos hormônios envolvidos no crescimento pré e pós-natal

1.2 Crianças nascidas pequenas para a idade gestacional

\subsubsection{Definição}

Os parâmetros utilizados para definir as crianças nascidas PIG são muito diversificados na literatura. Alguns autores consideram como PIG as crianças que apresentaram peso e/ou comprimento ao nascer abaixo do terceiro percentil para a idade gestacional, outros abaixo do quinto ou décimo percentil [29-31]. Contudo, a definição mais utilizada considera as crianças nascidas PIG como aquelas com peso e/ou comprimento ao nascimento abaixo de dois desvios-padrão da média para o sexo e a idade gestacional de uma determinada população [32, 33]. 
As curvas de crescimento de Usher e Mc Lean [34], feitas há quase quatro décadas avaliam o tamanho ao nascer de acordo com a idade gestacional (de 25 a 44 semanas), classificando os recém-natos em PIG, AIG (adequados para a idade gestacional) e GIG (grande para a idade gestacional) de acordo com os dados antropométricos ao nascimento (peso, comprimento, perímetro cefálico). Surgiram algumas curvas de crescimento $[35,36]$ ao longo desses anos que apontaram diferenças inter-população de acordo com o nível sócio-econômico, raça, altitude, e também pelo tamanho da amostra, mas todas utilizaram as curvas de Usher e Mc Lean como comparação, e até hoje essas curvas são utilizadas na maioria das unidades de terapia intensiva neonatal para a avaliação do crescimento intra-uterino [36].

\subsubsection{Morbidade e mortalidade}

Crianças nascidas PIG têm maior morbi-mortalidade no período perinatal e na vida adulta do que aquelas que nasceram adequadas para a idade gestacional. No período perinatal, apresentam mais freqüentemente hipospádia [37], além de complicações respiratórias, hipoglicemia, enterocolite necrotizante e morte neonatal [38, 39]. Na infância e na adolescência, podem apresentar alterações cognitivas e dificuldade de aprendizado [38-41]. Na vida adulta, além da baixa estatura, indivíduos nascidos PIG têm risco aumentado para doenças cardiovasculares, doença pulmonar obstrutiva, insuficiência renal, função reprodutiva alterada 
(hiperandrogenismo, síndrome dos ovários policísticos, disfunção gonadal), resistência insulínica e diabetes melito tipo 2 [42-46].

1.2.2.a Associação entre nascer PIG e a baixa estatura na idade adulta

Sabe-se que $3 \%$ das crianças nascem PIG, e que a grande maioria delas, cerca de 90\%, apresentam recuperação pôndero-estatural precocemente, independente da presença ou da ausência de prematuridade, normalizando o peso e estatura até os 2 anos de idade [47]. Entretanto, 10\% a $20 \%$ delas permanecem pequenas com estatura maior que -2 DP (desviopadrão) aos 2 anos de idade, e não apresentam recuperação posterior do crescimento, resultando em baixa estatura na vida adulta [48, 49]. A recuperação estatural (RE) é alcançada quando a altura do paciente estiver acima do terceiro percentil ou menor que -2 DP [5].

A RE dos prematuros pode ser um pouco mais lenta e ocorrer entre os dois e três anos de vida [50-53], porém há relatos de que esta recuperação pode ocorrer até os cinco ou seis anos de idade [54].

O menor comprimento ao nascimento parece ser o fator de risco mais importante para a baixa estatura persistente. Crianças com redução do peso ao nascimento têm um risco de 5,2 vezes maior de se tornarem adultos com baixa estatura, enquanto que, nos casos em que o comprimento ao nascimento esteve reduzido, o risco se eleva para 7,1 vezes [50]. A baixa estatura pode ser decorrente da maturação óssea acelerada $[55,56]$, ou ainda de fatores relacionados à ausência de RE nos primeiros anos de vida pós-natal. 
O estudo de genes que determinam o crescimento fetal é dificultado pela presença de fatores relacionados ao ambiente materno uterino, que agem sobre a oferta e a passagem transplacentária de nutrientes tais como paridade, tabagismo, nutrição e doenças maternas, entre outros. Após o nascimento, quando os efeitos do ambiente materno uterino não estão mais presentes, um grande percentual de bebês exibe recuperação pônderoestatural, assumindo sua trajetória de crescimento geneticamente determinada [57]. Nas crianças que não apresentam tal recuperação, o baixo peso possivelmente está também relacionado a fatores genéticos [58].

1.2.2.b Associação entre nascer PIG e o desenvolvimento de resistência insulínica e síndrome metabólica

Desde o início da década de 90, as concentrações séricas elevadas de insulina têm sido relacionadas à RCIU. Phipps et al. [59] publicaram um dos primeiros estudos relacionando menor tamanho ao nascimento com elevados níveis de insulina nos adultos. Desde então, vários autores têm demonstrado uma maior freqüência de resistência insulínica em crianças e adultos nascidos PIG, independente de outros fatores como IMC, idade, fumo, história familiar de diabetes melito tipo 2, entre outros [59-63]. Em 2006, um importante estudo prospectivo francês realizado em mais de 1500 adultos jovens mostrou, utilizando o índice QUICKI (689 AIG e 734 PIG) e, em parte dos indivíduos, do clamp euglicêmico hiperinsulinêmico (25 AIG e 26 PIG), uma sensibilidade insulínica menor nos indivíduos PIG, quando comparados aos indivíduos AIG [64]. 
A associação entre a presença de RE em crianças nascidas PIG e a resistência insulínica tem sido relatada por alguns autores [31, 65]. Soto et al. [60] evidenciaram maior resistência insulínica em crianças pré-púberes nascidas PIG com recuperação estatural em comparação àquelas PIG sem RE e AIG.

A associação entre nascer PIG e desenvolver síndrome metabólica foi bem demonstrada em dois grandes estudos. Barker et al. [66], em 1995, avaliaram indivíduos adultos com mais de 50 anos de idade que nasceram com menos de $2,5 \mathrm{Kg}$, e demonstraram que esses tinham 10 vezes mais risco de ter síndrome metabólica que os indivíduos que nasceram com mais de 4,5 Kg. Dez anos após, Jaquet et al. [67] observaram a presença de síndrome metabólica em $2,3 \%$ dos indivíduos adultos que nasceram PIG, e em $0,3 \%$ dos indivíduos que nasceram AIG.

Algumas teorias foram criadas para justificar o desenvolvimento de resistência insulínica em indivíduos nascidos PIG:

1) A teoria "thrifty genotype" modificada, primeiramente sugerida por Neel em 1962 [68], especula que genes como o da insulina e o seu polimorfismo VNTR possam promover o crescimento fetal em um ambiente desfavorável, e também provocar o desenvolvimento de insulino-resistência em um ambiente pós-natal favorável.

2) A teoria "thrifty phenotype", proposta há mais de uma década por Hales e Barker, infere que a sub-nutrição na vida intra-uterina pode levar a síndrome metabólica ou diabetes melito tipo 2 na vida adulta [66]. A subnutrição em fases críticas do desenvolvimento fetal gera baixo peso e uma diminuição 
das necessidades metabólicas [69], o que determina menor secreção de hormônios anabólicos como a insulina, e aumento de hormônios catabólicos, levando a um menor uso de glicose e a um aumento da oxidação de outros substratos como aminoácidos e lactato [70], o que corresponde a uma "programação metabólica" direcionada para a "conservação de glicose". Esse processo provoca mudança na sensibilidade à insulina e uma redução da massa de células $\beta$ pancreáticas, as quais, embora adequadas para manter a homeostase glicêmica por um período, pode predispor ao diabetes melito tipo 2 na vida adulta, numa fase em que a oferta nutricional seja adequada . É possível que a insulino-resistência do adulto seja decorrente do mesmo processo que leva à redução da oxidação de glicose em tecidos insulino-sensíveis, originada, portanto, na vida intra-uterina [71].

O esquema abaixo resume a teoria "thrifty phenotype"

Desnutrição intra-uterina $\rightarrow$ baixo peso $\rightarrow$ programação metabólica $\rightarrow$ síndrome de resistência à insulina no adulto

3) Em contraposição às hipóteses descritas acima, a relação entre o baixo peso e a resistência à insulina pode ser explicada pela ação de genes expressos tanto no feto, quanto no adulto. Estudos em animais knockout [69, 72] e descrições de mutações em humanos [3, 73, 74] identificaram vários genes importantes na determinação do crescimento fetal, tais como os genes IGF1, IGF2 e insulina com seus respectivos receptores. O IGF1 e a insulina são importantes fatores de crescimento pré e pós-natal. O IGF2 
estimula o crescimento celular por mecanismos autócrinos e parácrinos [75], sendo o hormônio mais envolvido no desenvolvimento fetal [76].

É possível que a menor produção de insulina ou a resistência à sua ação sejam geneticamente determinadas, resultando em crescimento fetal deficiente e em síndrome metabólica durante a infância e a vida adulta [77]. Além disso, demonstrou-se, através da análise de polimorfismos, que a região INS-IGF2-TH do cromossomo $11 \mathrm{p} 15$, representado pelos genes da insulina, IGF2 e da tirosina hidroxilase, respectivamente, apresenta forte associação com o índice de massa corpórea (IMC) e risco para doença cardiovascular em adultos [78, 79]. De acordo com essa hipótese, fatores genéticos poligênicos produziriam 2 fenótipos: o bebê de baixo peso e 0 adulto com risco de diabetes melito tipo 2, hipertensão arterial e doença aterosclerótica, ambos manifestações da mesma causa básica.

\subsection{2.c Associação entre nascer PIG e a presença de hipospádia}

Hipospádia é uma das mais freqüentes anomalias congênitas, afetando um de cada 250 a 300 nascidos vivos [80]. Gatti et al. [80] observaram prevalência de hipospádia proximal, medial e distal em $11 \%$ de um grupo de 154 recém-nascidos PIG, ao passo que a prevalência de hipospádia na população geral é de aproximadamente 1\%. Hussain et al. [37], analisando um grupo de 6738 recém-nascidos masculinos, mostraram prevalência de hipospádia em 3,8\% nos neonatos PIG, 1,3\% nos AIG e 0,4\% nos GIG.

A patogênese da hipospádia em indivíduos com retardo de crescimento intra-uterino é motivo de controvérsias. É possível que algum evento no $1^{\circ}$ 
trimestre da gestação, quando ocorre a diferenciação genital, afete adversamente o crescimento fetal e a diferenciação uretral [80]. Evidências recentes em estudos com animais [81] e humanos [82] sugerem uma correlação entre anormalidades genitais masculinas e fatores ambientais (estrógenos e compostos anti-androgênicos do meio). Entretanto, isso não exclui que anormalidades genéticas ou polimorfismos determinem maior vulnerabilidade aos efeitos de agressores ambientais [83].

O desenvolvimento da genitália externa masculina é primariamente regulado por andrógenos. Entretanto, várias evidências indicam que fatores de crescimento como IGF1, IGF2 e IGFBPs, podem agir como mediadores da ação androgênica em tecidos andrógeno-responsivos, uma vez que pacientes com deficiência congênita de GH apresentam micropênis, apesar da produção androgênica normal [84].

Ashton et al. [85] mostraram, em cultura de células de fibroblastos de prepúcio de recém-nascidos, que a testosterona no meio de cultura aumentou significativamente a produção de IGF1 e IGFBP pelas células, e que, após a incubação com anticorpo anti-IGF1, houve redução da proliferação celular. Essa observação sugere que a testosterona estimula a proliferação desse tecido andrógeno-responsivo, em parte, pelo aumento da produção local de IGF1 e IGFBP.

Elmlinger et al. [86] estudaram a expressão dos genes IGF2, IGF1 e IGFBPs em cultura de fibroblasto de pele genital de pacientes com insensibilidade completa aos andrógenos (CAIS), e em homens normalmente virilizados. Observaram menor expressão dos genes IGF2 e IGFBP2 em CAIS, demonstrando o efeito autócrino/parácrino do IGF2 e 
IGFBP2 como mediador da ação celular do andrógeno em tecidos andrógeno-responsivos.

Em resumo, há evidências de que a diminuição da expressão, na vida fetal, de genes como o IGF2 e/ou IGF1 podem causar retardo de crescimento intra-uterino e maior risco de hipospádia.

1.3 Modelos animais de Retardo de Crescimento Intra-uterino

Baker et al. [72] e Liu et al. [87] criaram camundongos knockout para os genes Igf1, Igf2, Igf1r e Igf2r. Os animais knockout, tanto para o gene Igf1, como para o Igf2, apresentaram um importante grau de RCIU, comprovando a importância desses dois hormônios no crescimento fetal [72]. Os animais duplo knockout de Igf1r e Igf1, ou somente de Igf1r, apresentaram um déficit de crescimento grave [87]. Os animais duplo knockout lgf1/lgf2 demonstraram déficit de crescimento mais grave, semelhante aos animais duplo knockout lgf-1r/lgf2 [87]. Os animais duplo knockout lgf2/lgf2r apresentaram um leve retardo do crescimento, pois o principal receptor do Igf2 é Igf1r [72]. O knockout de genes que codificam as IGFBPs, a sub-unidade ácido-lábil (ALS), outros hormônios e receptores como a insulina e o receptor do $\mathrm{GH}$, influenciam de forma menos expressiva no desenvolvimento pré-natal [88-93] (Tabela 1). 
Tabela 1: Porcentagem de redução do peso de camundongos knockout para os genes envolvidos no crescimento pré-natal.

\begin{tabular}{ccc}
\hline Gene(s) deletado(s) & $\begin{array}{c}\text { \% do peso em relação } \\
\text { ao controle }\end{array}$ & Referência \\
\hline Igf2 e Igf2r & 75 & {$[72]$} \\
Igf1 ou lgf2 & 60 & {$[72]$} \\
Igf1r & 45 & {$[87]$} \\
Igf1r e Igf1 & 45 & {$[87]$} \\
Igf1r e Igf2 & 30 & {$[87]$} \\
Igf1 e Igf2 & 30 & {$[87]$} \\
Insr & 78 & {$[93]$} \\
Ins & 78 & {$[89]$} \\
Ghr & 83 & {$[88]$} \\
Als & 90 & {$[92]$} \\
\hline
\end{tabular}

Constância et al. [94] demonstraram que camundongos fêmeas knockout para região promotora P0 (expressa exclusivamente na placenta do camundongo) do IGF2 apresentaram hipodesenvolvimento placentário, o que determinou uma restrição do crescimento fetal após a metade da gestação, devido a alterações na passagem transplacentária de nutrientes.

De Chiara et al. [95], pela geração de camundongos transgênicos carreadores de uma deleção no gene IGF2, demonstraram em quatro gerações que os animais apresentavam déficit pôndero-estatural ao nascimento, quando a mutação era transmitida pelo alelo paterno, concluindo que o gene IGF2 está envolvido no crescimento fetal e sofre Imprinting parental materno. 
1.4 Genes envolvidos no crescimento pré e pós-natal em humanos

O interesse na identificação de fatores controladores do peso e comprimento ao nascimento cresceu na última década, principalmente após a publicação de estudos que mostraram associação entre baixo peso ao nascimento e doenças na idade adulta, tais como diabetes melito tipo 2, hipertensão arterial, dislipidemia e doença cardiovascular.

Nascer PIG e a baixa estatura na vida pós-natal são entidades clínicas complexas e, provavelmente, têm etiologia poligênica. Como descrito acima, existem vários modelos animais mostrando a importância da insulina, IGF1, IGF2 e seus receptores no crescimento fetal. Ogilvy-Stuart et al. [96] mostraram que recém-nascidos com alteração no desenvolvimento pancreático, ou na ativação do receptor de insulina, apresentavam RCIU, evidenciando a importância da insulina no crescimento fetal.

Mutações nos genes IGF1 e IGF1-R têm sido identificadas em pacientes que apresentaram grave retardo no crescimento pré e pós-natal $[3,97,98]$. Mais recentemente, mutações na região telomérica de imprinting no cromossomo 11p15, resultando em super-metilação e sub-expressão do IGF2, foram descritas em algumas crianças com a síndrome de SilverRussell [99]. Por outro lado, a hiperexpressão do gene IGF2 determina o supercrescimento fetal observado na síndrome de Beckwith-Wiedemann [74].

Em relação ao gene IGF2- $R$, não há mutações descritas, mas a variabilidade do grau de imprinting e sua expressão gênica relacionam-se com o tamanho ao nascimento [100]. Até o momento, nenhuma mutação nos 
genes que codificam as IGFBPs foi identificada em recém-nascidos com RCIU. Recentemente, um trabalho de revisão reuniu vários estudos, ainda controversos, que evidenciaram a importância dos polimorfismos na expressão de genes envolvidos no crescimento fetal e pós-natal [101].

\subsubsection{Polimorfismo $(\mathrm{CA})_{\mathrm{n}}$ da região promotora do gene IGF1}

O gene IGF-1 está localizado no braço longo do cromossomo 12 (12q 22 - 24.1), é constituído de seis exons e mede $85 \mathrm{~Kb}$. Esse gene codifica duas proteínas, produtos de splice alternativo nos exons 5 e 6: a IGF1-A, que contém 153 aa codificados pelos exons 1, 2, 3, 4 e 6; e a IGF1-B, com 195 aa codificados pelos exons 1,2,3,4 e 5. Especula-se que o IGF1-B exerce seu papel principal na vida intra-uterina, enquanto que a mesma função é exercida, na vida pós-natal, pelo IGF1-A [97].

Diversos polimorfismos foram identificados no gene IGF1 e os estudos que avaliam a associação desses polimorfismos com o peso ao nascimento são bastante controversos. O polimorfismo $(C A)_{n}$ é um microssatélite representado por uma seqüência de repetições citosinaadenina localizada na região promotora do gene IGF1. De acordo com o número de repetições, 10 diferentes alelos (182, 184-198, 200 pb) foram identificados. De acordo com estudos populacionais, $88 \%$ dos indivíduos são portadores de pelo menos um alelo com 192 pb (marcador 737/738), sugerindo que este é o alelo nativo, e que pode influenciar na produção de IGF1 [102-104]. 
Vaessen et al. [103] observaram uma associação entre o polimorfismo $(\mathrm{CA})_{\mathrm{n}}$ e o baixo peso ao nascimento. Estudando 463 indivíduos, os autores mostraram que a ausência do alelo 192 pb determinou um peso ao nascimento $215 \mathrm{~g}$ inferior ao dos homozigotos para esse alelo. Em outro estudo, envolvendo 900 participantes, esses autores mostraram que indivíduos não carreadores do alelo 192 pb apresentavam menor estatura, menores concentrações séricas de IGF1, maior risco de desenvolver diabetes melito tipo 2, e infarto agudo do miocárdio.

Por outro lado, dois outros estudos mostraram que os indivíduos carreadores do alelo $192 \mathrm{pb}$ apresentavam menores concentrações séricas de IGF1 [102, 104]. Além disso, Frayling et al. [104] não observaram diferenças na sensibilidade à insulina, no peso ao nascimento, nem na presença ou na ausência de RE entre os indivíduos carreadores ou não do alelo $192 \mathrm{pb}$.

Johnston et al. [105], em 1999, analisaram outros polimorfismos localizados no gene IGF1 em crianças nascidas PIG e AIG, e não observaram correlação com o tamanho ao nascimento. Por outro lado, Arends et al. [106], em 2002, identificaram uma correlação direta entre um polimorfismo localizado no íntron 2 de repetições CT (marcador IGF1/PCR1) e as concentrações séricas de IGF1, perímetro cefálico ao nascimento, peso e comprimento ao nascimento, além da baixa estatura na vida adulta. Nesse mesmo estudo, os autores observaram que os pais da crianças nascidas PIG,carreadores do alelo $198 \mathrm{pb}$, eram significantemente mais baixos que os pais não carreadores. Apenas uma criança no estudo era portadora desse 
alelo sugerindo que esse pode estar relacionado com a baixa estatura, mas não com o peso ao nascimento.

Podemos observar que a correlação dos polimorfismos do gene IGF1 com tamanho ao nascimento e as concentrações séricas de IGF1 é controversa, permanecendo, assim, a necessidade de novos estudos para se estabelecer a relação dos diversos polimorfismos localizados no gene IGF1 com o peso ao nascer, as concentrações séricas de IGF1 e a presença de RE.

1.4.2 Polimorfismo VNTR do gene da insulina

O gene da insulina está localizado no braço curto do cromossomo 11, região $11 \mathrm{p} 15$. O polimorfismo VNTR (variable number of tandem repeat) do gene da insulina é um candidato ao estudo de associação entre baixo peso ao nascimento e síndrome de resistência à insulina [107]. Os VNTRs são polimorfismos amplamente dispersos no genoma que consistem em repetições de seqüências fixas de DNA, geralmente encontradas em regiões não codificadoras.

O VNTR do gene da insulina (VNTR INS) está localizado a 596 pares de bases antes do códon de início da transcrição. É constituído por repetições variáveis do oligonucleotídeo ACAGGGGT(G/C)(T/C)GGGG [108], podendo ser dividido em 3 classes de acordo com o número de repetições: o alelo classe I com 26 a 63 repetições (aproximadamente 570 pb), o alelo classe II com 64 a 140 repetições (aproximadamente 1200 pb) e 
o alelo classe III com 141 a 209 repetições (aproximadamente 2200 pb) [109].

Paquette et al. [110] utilizando estudos in vivo (placenta) e in vitro (hepatócitos), mostraram que a variação do comprimento do polimorfismo VNTR INS regula os diferentes graus de transcrição do gene da insulina e de seu gene contíguo IGF2.

Esses estudos tentam justificar o efeito protetor do VNTR classe III sobre o risco de diabetes melito tipo 1, mostrando que esse alelo está associado a menores níveis de RNAm da insulina em pâncreas humano fetal e adulto [111, 112], enquanto no timo fetal esse alelo causa maior expressão de insulina $[113,114]$. O aumento da expressão do gene da insulina no timo fetal possivelmente causa maior tolerância imunológica a esse antígeno, justificando seu efeito protetor contra a destruição auto-imune da célula $\beta$, já que a insulina é o único auto-antígeno específico da célula $\beta$. Os autores não comentaram sobre a expressão do gene da insulina com o risco de diabetes melito tipo 2 e a síndrome metabólica.

Dunger et al. [107] mostraram associação do genótipo III/III com maior peso, comprimento e, principalmente, maior perímetro cefálico ao nascimento. Em outra coorte, os mesmos autores confirmaram a relação de maior perímetro cefálico e a transmissão parental do alelo classe III [115].

Lindsay et al. [58] estudaram o genótipo VNTR INS em 660 índios Pima, avaliados por teste de tolerância oral à glicose, cujos pesos ao nascimento estavam catalogados. Antes da análise, o peso ao nascer foi ajustado para o sexo e a idade gestacional, utilizando como parâmetro 
dados da mesma população em que o status de diabetes materno foi considerado. Foi demonstrada uma associação significativa entre o VNTR INS classe III, baixo peso ao nascimento e diabetes melito tipo 2, pois esse alelo estava em desequilíbrio de ligação com esses dois fenótipos.

Ong et al. [116] detectaram associação significativa entre o genótipo III/III e a presença de diabetes melito tipo 2 em um grupo de 105 homens com baixo peso ao nascer que não apresentaram recuperação estatural no primeiro ano de vida. A relação entre baixo peso e diabetes ocorreu de forma independente do VNTR INS, sugerindo que os fatores que restringem o crescimento fetal, e que aumentam a suscetibilidade a doenças, atuam de forma independente e adicional ao VNTR INS.

Por outro lado, Dunger et al. [107] estudaram o genótipo VNTR INS de 758 crianças com pesos variados, acompanhadas desde o nascimento até os dois anos de vida. Do total, $45 \%$ não apresentaram RE e, nesse grupo, houve associação significativa entre a homozigose do alelo I (I/I) com menor peso, menor comprimento e menor perímetro cefálico ao nascimento.

Ibanéz et al. [117] estudaram o genótipo VNTR INS em 141 meninas com pubarca precoce e 141 meninas normais. A distribuição do genótipo foi semelhante nos 2 grupos, mas, no grupo com pubarca precoce, as homozigotas e heterozigotas para o alelo I $\left(\mathrm{I} /{ }^{*}\right)$ apresentaram menor peso ao nascimento, menor sensibilidade à insulina (avaliada pelo índice HOMA-IR) e perfil lipídico desfavorável, quando comparadas às homozigotas para o alelo III (III/III). Para avaliar os efeitos do VNTR classe I e do peso ao nascimento isoladamente sobre o perfil metabólico, foi realizada uma 
comparação entre os subgrupos $1 /^{*}$ baixo peso, $1 /^{*}$ peso normal e III/III, sendo evidenciados efeitos adversos independentes e aditivos do baixo peso e do genótipo $1 /{ }^{*}$. Os autores concluíram que esta é uma evidência da interação genético-ambiental afetando o fenótipo endócrino-metabólico dos indivíduos.

Bennett et al. [118] estudaram o polimorfismo do VNTR INS em 5646 indivíduos adequados para a idade gestacional e não encontraram associação desse polimorfismo com peso, comprimento e perímetro cefálico ao nascimento.

Mitchell et al. [119], pela análise do polimorfismo do VNTR INS em 1184 crianças e em 1009 pais (todos AIG), provenientes de 3 populações diferentes, concluíram que não houve evidência de crescimento fetal alterado associado ao genótipo VNTR INS, mesmo analisando-se o efeito da origem parental do alelo presente. No entanto, encontraram associação positiva do alelo classe III com a resistência à insulina nos adultos de uma das populações.

VU-Hong et al. [120] estudaram o VNTR INS numa população de indivíduos nascidos PIG ( $n=735)$ e AIG ( $n=886)$, e não encontraram relação desse polimorfismo com o tamanho ao nascimento. Entretanto, encontraram associação do alelo classe III com maior resistência à insulina nos adultos nascidos PIG. Mook-Kanamori et al. [121] estudaram o VNTR INS em 859 crianças e encontraram relação de menor idade gestacional ao nascimento em homozigotos classe III e nenhuma associação com tamanho ao nascer. 
Conhecendo-se a origem multifatorial da síndrome de resistência à insulina, o VNTR INS pode representar um fator genético de risco. É possível que o alelo classe III do VNTR INS represente risco para baixo peso ao nascimento e, de acordo com estudos funcionais que mostraram menor transcrição do gene da insulina em pâncreas humano, pode ser considerada a hipótese de que esse alelo também esteja associado a risco para diabetes melito tipo 2 e à síndrome metabólica.

\subsubsection{Região promotora P4 do gene IGF2}

O gene IGF2 mede $30 \mathrm{~Kb}$ e é constituído por 4 exons. Apenas os exons 2, 3 e parte do 4 codificam a pré-proteína IGF2 que é constituída por 180 aminoácidos (Genebank no 10982-110598). O IGF2 contém 67 aminoácidos e possui homologia de $50 \%$ com a insulina e o IGF1. O gene IGF2 está localizado no cromossomo 11 na posição 11 p15 adjacente ao gene da insulina [122-124]; devido a proximidade física com o gene da insulina, o VNTR INS exerce um controle sobre a expressão do gene IGF2 como ocorre com o gene da insulina $[110,125]$.

Os exons 1 e 2 do gene IGF2 são precedidos por promotores independentes P1, P0, P2, e P3, antes do exon 1, e P4 antes do exon 2, originando vários transcritos de diferentes pesos moleculares [126, 127] (Figura 2). O promotor P1 é ativo no fígado adulto, enquanto que o P2, P3 e P4 são promotores ativos nos tecidos fetais [128-130].

A transcrição do gene IGF2 é controlada de modo tecido-específico e é dependente da fase do desenvolvimento. Os promotores P3 e P4 são 
expressos em todos os tecidos fetais, inclusive no fígado. No entanto, nos tecidos adultos, o P2, P3 e P4 permanecem ativos em tecidos não hepáticos, mas no fígado sofrem down-regulation e o promotor $\mathrm{P} 1$ torna-se ativado [131].

O promotor P4 localiza-se a 1660 nucleotídeos antes do sítio de início de transcrição do exon 2 e é composto, em sua maioria, de pares de base GC $[126,132]$.

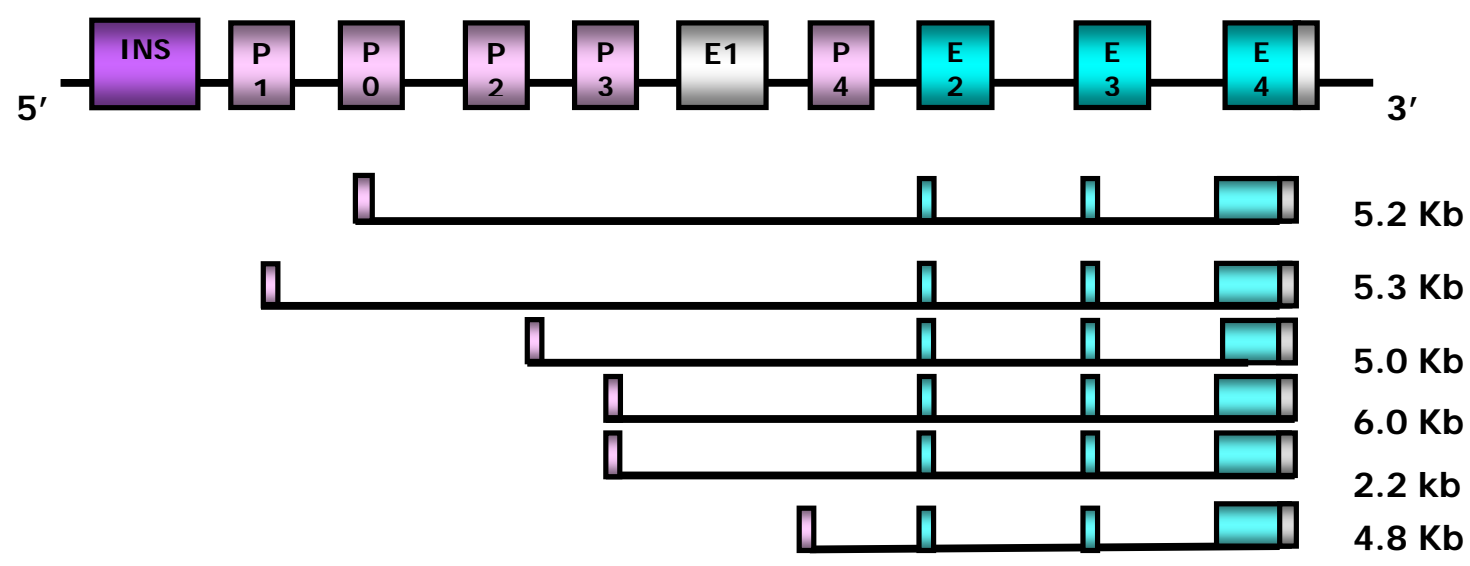

Figura 2: Representação do gene IGF2 com exons (E), regiões promotoras $(P)$ e diferentes transcritos.

Em humanos, estudos de polimorfismos do gene IGF2 sugeriram que variações genéticas nesse gene são determinantes do IMC em homens de meia-idade $[133,134]$. No entanto, até o momento, não há estudos da região promotora P4 gene IGF2, uma das regiões promotoras mais expressa na vida intra-uterina, em crianças com baixo peso ao nascimento. 
Um crescente número de publicações evidenciam a associação de baixo peso e/ou estatura ao nascimento com aparecimento de distúrbios na idade adulta, como diabetes melito tipo 2, hipertensão arterial, dislipidemia, doença cardiovascular e baixa estatura $[49,66,147]$. Contudo, o mecanismo pelo qual o retardo do crescimento fetal pode causar tais alterações ainda não está definido. O estudo do crescimento e dos fatores endócrinos em crianças nascidas PIG e a investigação de genes candidatos, como IGF2, IGF1, e da insulina, podem ajudar na compreensão dos mecanismos envolvidos nas conseqüências clínicas do nascer PIG.

A influência isolada dos polimorfismos $(\mathrm{CA})_{\mathrm{n}}$ do gene IGF1 e VNTR INS do gene da insulina no tamanho ao nascimento é bastante controversa na literatura. Por outro lado, estudos recentes em modelos animais mostram a importância do gene IGF2 no crescimento intra-uterino. Além disso, tem sido sugerido que o VNTR INS modula a expressão dos genes da insulina e do IGF2, porém nenhum estudo, até o momento, analisou a possível ligação de polimorfismos dos genes da insulina e do IGF2. Diante disso, a nossa proposta foi analisar a influência desses genes isoladamente e em conjunto no crescimento pré e pós-natal. 
Objetivos 
Analisar em crianças nascidas PIG com e sem RE:

1. A distribuição e a freqüência das classes I e III do VNTR INS e das repetições CA do gene IGF1;

2. A influência do VNTR INS e das repetições CA do gene IGF1 na sensibilidade à insulina e nas concentrações séricas de IGF1, respectivamente;

3. A região promotora $\mathrm{P} 4$ do gene IGF2. 
Casuística e Métodos 


\subsection{CASUÍSTICA}

Critérios de Inclusão:

Grupo de estudo: indivíduos nascidos PIG (abaixo de -2 desviospadrão da média para sexo e idade) de acordo com as tabelas de peso e/ou comprimento de Usher and McLean, 1969 [135, 136]. Todas as crianças do grupo de estudo estão em seguimento ambulatorial regular em três diferentes centros (Tabela 2):

1-Unidade de Endocrinologia do Desenvolvimento da Disciplina de Endocrinologia do HC-FMUSP (ambulatórios, de baixa estatura idiopática e de genitália ambígua).

2-Unidade de Endocrinologia Pediátrica da Santa Casa de Misericórdia de São Paulo (ambulatório de seguimento de prematuros).

3-Unidade de Endocrinologia Pediátrica do Hospital das Clínicas de Curitiba da UFPR.

Tabela 2: Distribuição do grupo de estudo de acordo com os centros de origem.

\begin{tabular}{|c|c|c|c|c|c|}
\hline PIG & & $\begin{array}{l}\text { Com RE } \\
n=66\end{array}$ & & $\begin{array}{l}\text { Sem RE } \\
n=76\end{array}$ & \\
\hline $\begin{array}{l}\text { Ambulatório } \\
\text { Origem }\end{array}$ & de & $\begin{array}{l}\text { Masculino } \\
n=33\end{array}$ & $\begin{array}{l}\text { Feminino } \\
\mathrm{n}=33\end{array}$ & $\begin{array}{l}\text { Masculino } \\
n=43\end{array}$ & $\begin{array}{l}\text { Feminino } \\
n=33\end{array}$ \\
\hline HC-FMUSP & & 6 & 0 & 26 & 18 \\
\hline Santa Casa-SP & & 23 & 30 & 7 & 10 \\
\hline HC-UFPR & & 4 & 3 & 10 & 5 \\
\hline
\end{tabular}

O Grupo de crianças PIG com idade $\geq 2$ anos foi subdividido em com RE (acima de -2 desvios-padrão da média para sexo e idade) e sem RE (abaixo de -2 desvios-padrão da média para sexo e idade), através das 
tabelas de altura United Kingdom, 1990 [137]. Foram consideradas crianças sem recuperação estatural aquelas que não haviam recuperado espontaneamente a estatura após os dois anos de idade e que apresentaram estabilização do escore de desvio-padrão para estatura por pelo menos seis meses.

O grupo controle constituiu-se de indivíduos nascidos AIG do banco de DNA de papel filtro do Laboratório de Hormônios e Genética Molecular LIM/42 (acima de -2 desvios-padrão da média para sexo e idade) classificadas de acordo com as tabelas de peso e/ou comprimento de Usher and McLean, 1969 [135, 136]. Esse grupo foi utilizado somente para análise molecular.

Critérios de exclusão:

Cromossomopatias, síndromes gênicas (exceto Silver Russell), múltiplas malformações congênitas, infecções de repetição, doenças neurológicas, cardiopatias, doenças pulmonares crônicas, nefropatias, máabsorção intestinal e uso crônico de medicações.

Nos pacientes PIG com hipospádia de causa indeterminada, os defeitos na síntese da testosterona e deficiência da $5 \alpha$-redutase tipo 2 foram afastados pelo teste de estímulo com hCG. O estudo molecular do receptor androgênico (RA) afastou a presença de mutações no gene do RA nesses pacientes.

Cada paciente ou responsável foi informado a respeito da pesquisa, e assinou o termo de consentimento livre e esclarecido para a participação (anexo B). O projeto foi aprovado pela comissão de ética do HC-FMUSP (CAPPesq). 


\subsubsection{Grupo Controle}

Foram selecionados 297 indivíduos que nasceram AIG, sendo 145 do sexo masculino e 152 do sexo feminino. A média da idade gestacional foi $39 \pm 1,6$ semanas; do peso ao nascimento foi $3,1 \pm 0,32 \mathrm{Kg}$, e do comprimento ao nascimento foi $48,2 \pm 2,0 \mathrm{~cm}$.

\subsubsection{Grupo de estudo}

O grupo foi composto por 142 indivíduos nascidos PIG, de ambos os sexos, com idade de dois a dezessete anos, e foi dividido em 2 subgrupos: 66 crianças com recuperação estatural (33 do sexo masculino), sendo que 5 apresentavam hipospádia idiopática e 76 crianças sem recuperação estatural (43 do sexo masculino), sendo que 2 apresentavam hipospádia idiopática. Temos 5 crianças com síndrome de Silver Russell, todas sem RE, sendo 3 do sexo masculino e 2 do sexo feminino.

\subsection{MÉTODOS}

\subsubsection{Avaliação clínica}

Os dados antropométricos ao nascimento (idade gestacional, peso, comprimento e perímetro cefálico) foram obtidos através dos prontuários médicos, assim como as intercorrências clínicas e patológicas. As condições maternas [diabetes melito gestacional (DMG), doença hipertensiva específica da gestação (DHEG), fumo, Hipertensão e diabetes prévios a gestação] foram obtidas a partir das fichas de acompanhamento pré-natal e questionário do protocolo de pesquisa (anexo A).

Os indivíduos foram classificados como PIG ou AIG de acordo com as 
tabelas de peso e/ou comprimento de Usher and Mc Lean, 1969, através do software Growth Analyser 3, bem como a análise do perímetro cefálico ao nascer dos indivíduos classificados como PIG [135, 136, 138].

A presença de recuperação estatural foi estabelecida quando a altura das crianças nascidas PIG, com idade $\geq 2$ anos, estava acima de -2 desvios-padrão da média para sexo e idade de acordo com as tabelas de altura United Kingdom, 1990 do programa Growth Analyser 3 [137]. A estatura alvo foi calculada através da fórmula: altura do pai $(\mathrm{cm})+$ altura da mãe $(\mathrm{cm}) / 2 \pm 6,5 \mathrm{~cm}[139]$.

\subsubsection{Avaliação bioquímica e hormonal}

A dosagem da glicose foi realizada pelo método colorimétrico enzimático (glicose-oxidase) [140] com valor mínimo detectável de $2 \mathrm{mg} / \mathrm{dl}$, precisão intra-ensaio sendo $<1 \%$ e inter-ensaio $<2 \%$. A insulina foi determinada pelo método fluoroimunométrico (IFMA) [141, 142] baseado na técnica "sanduíche", na qual dois anticorpos monoclonais são dirigidos contra determinantes antigênicos da molécula de insulina. A insulina das amostras reage simultaneamente com os anticorpos imobilizados na fase sólida e com os anticorpos marcados com európio. A fluorescência de cada dosagem é diretamente proporcional à concentração de insulina da amostra. O valor mínimo detectável pelo método é $0,5 \mu \mathrm{U} / \mathrm{ml}$, e a precisão intra e interensaio é < 4\%. A resistência insulínica foi determinada pelo índice HOMA-IR [fórmula: Insulina de jejum( $\mu \mathrm{U} / \mathrm{ml})$ X Glicemia de jejum(mmol/l) / 22,5] [143].

As concentrações séricas de IGF1 foram dosadas pelos métodos: imunoradiométrico (IRMA) e imunoquimioluminométrico (IQMA) [122, 144], 
sendo os valores calculados em desvio-padrão para sexo e idade. O método IRMA foi primeiramente descrito por Miles e Hales, em 1968 [145]. O Kit da Diagnostic Systems Laboratories (Webster, Texas, USA) inclui uma etapa importante para uma determinação mais precisa das concentrações de IGF1, na qual o IGF1 é separado da sua proteína de ligação no soro. O IRMA é um ensaio não competitivo de fase sólida que utiliza dois anticorpos dirigidos contra o IGF1. O primeiro anticorpo é imobilizado na parede do tubo de ensaio e o segundo anticorpo é marcado com iodo radioativo. O IGF1 presente na amostra se liga aos dois anticorpos e forma um complexo tipo "sanduíche", portanto a radioatividade medida é diretamente proporcional à concentração de IGF1 na amostra. O valor mínimo detectável pelo método é de $24 \mathrm{ng} / \mathrm{ml}$, e a precisão intra-ensaio é $<4 \%$ e inter-ensaio é $<9 \%$.

O método IQMA, descrito por Daughaday e Rotwein [122], em 1989, também é um ensaio não competitivo de fase sólida, utilizando uma enzima fosfatase alcalina como marcador. No Kit da Diagnostic Products Corporation (Los Angeles, CA, USA), também ocorre o pré-tratamento da amostra, no entanto esse é realizado em um passo de diluição prévia no próprio aparelho IMMULITE 2000, no qual deve ocorrer uma extração ácida do IGF1 de suas proteínas [144]. O valor mínimo detectável pelo método é 25ng/ml, e a precisão intra-ensaio é < 4\% e inter-ensaio é < $9 \%$.

As concentrações séricas de IGF2 foram dosadas em poucos indivíduos pelo método imunoradiométrico (IRMA) [122], sendo os valores de referência calculados em desvio-padrão para idade. As dosagens foram realizadas no Quest Diagnostics Nichols Institute (San Juan Capistrano, CA, USA) pelo Kit da Diagnostic System Laboratories (Wesbster, Texas, USA). O 
valor mínimo detectável pelo método é $2,2 \mathrm{ng} / \mathrm{ml}$, e a precisão intra-ensaio é $<7 \%$ e inter-ensaio $<8 \%$.

\subsubsection{Análise molecular}

O DNA genômico foi extraído de cada paciente a partir de amostras de sangue periférico, coletadas em tubos "vacutainer" com EDTA, ou em papel filtro, utilizando o método "salting out" adaptado de Millers et al. [146].

3.2.3a Extração de DNA a partir de sangue periférico colhido em tubos com EDTA

Num tubo contendo $10 \mathrm{~mL}$ de sangue periférico foi adicionado o dobro do volume de tampão de lise de glóbulos vermelhos $(114 \mathrm{mM} \mathrm{NH} 4 \mathrm{Cl}, 1 \mathrm{mM}$ NaHCO3). Esta solução foi incubada por 30 minutos no gelo, prosseguindose uma centrifugação a $3000 \mathrm{rpm} / 4^{\circ} \mathrm{C} / 15 \mathrm{~min}$. O sobrenadante foi descartado e o procedimento de lise de hemácias foi repetido por mais uma vez. 0 botão de leucócitos foi suspenso em $9 \mathrm{~mL}$ de solução de lise de glóbulos brancos (100 mM NaCl, 10 mM Tris-HCl, p H8,0; 1 mM EDTA, pH 8,0) com $180 \mu \mathrm{L}$ de dodecilsulfato de sódio a $10 \%$ (SDS) e $150 \mu \mathrm{L}$ de proteinase $\mathrm{K}$ (10 mg/mL) (Gibco BRL, Gaitherburg, MD, USA) e este foi incubado a $37^{\circ} \mathrm{C}$ por toda a noite.

Após este período, foram adicionados $3,6 \mathrm{~mL}$ de solução saturada de cloreto de sódio (6 M), agitando-se vigorosamente por 15 segundos. O material foi centrifugado a $3000 \mathrm{rpm} / 15 \mathrm{~min}$. O sobrenadante foi transferido para um novo tubo e o DNA acabou precipitado pela adição de dois volumes 
de etanol absoluto gelado, homogeneizando-se a solução cuidadosamente por inversão. O DNA foi retirado do tubo e lavado com etanol $70 \%$ durante 5 minutos, repetindo-se este procedimento por mais três vezes. Por último, o DNA foi lavado em etanol absoluto e secado por centrifugação a vácuo. O DNA foi, então, ressuspendido em tampão TE a 10:0,1 (10 mM Tris-HCl, pH 8,0; 0,1 mM EDTA pH 8,0).

3.2.3b Extração de DNA a partir de sangue periférico fixado em papel filtro

Com o auxilio de um bisturi novo e de uma pinça, fragmentos de \pm 1 cm de diâmetro foram recortados do papel filtro contendo a amostra de sangue e colocados num tubo de microcentrífuga. Neste tubo, foram adicionados 1,5 $\mathrm{mL}$ de tampão de lise de glóbulos vermelhos (1 mM $\mathrm{NH}_{4} \mathrm{HCO}_{3}$ e $114 \mathrm{mM} \mathrm{NH}{ }_{4} \mathrm{Cl}$ ). A solução foi rapidamente vortexada, incubada por 30 minutos no gelo, e centrifugada a $6000 \mathrm{rpm} / 15 \mathrm{~min}$. O sobrenadante foi descartado e o procedimento de lise das hemácias repetido por mais duas vezes. O botão de células brancas foi, então, lisado pela incubação a $37^{\circ} \mathrm{C}$ durante a noite com $0,5 \mathrm{~mL}$ de uma solução contendo $10 \mathrm{mM}$ Tris $\mathrm{HCl}$ (pH 8,0), 10 mM EDTA (pH 8,0), $150 \mathrm{mM} \mathrm{NaCl,} \mathrm{0,2 \%} \mathrm{SDS} \mathrm{e} 300 \mu \mathrm{g} / \mathrm{ml}$ de proteinase $\mathrm{K}$.

No dia seguinte, foi colocado $0,2 \mathrm{~mL}$ de $\mathrm{NaCl}(6 \mathrm{M})$, e o material foi vortexado por 15 segundos e centrifugado a $14000 \mathrm{rpm} / 15 \mathrm{~min}$. O sobrenadante obtido foi transferido para um novo tubo de microcentrífuga, no qual foram adicionados dois volumes de etanol absoluto gelado para precipitação do DNA. A solução foi rapidamente homogeneizada por 
inversão e centrifugada a $6000 \mathrm{rpm} / 5 \mathrm{~min}$. O sobrenadante foi descartado e o pellet de DNA foi lavado com $1 \mathrm{~mL}$ de etanol 70\% gelado, prosseguindo-se nova centrifugação a $6000 \mathrm{rpm} / 5 \mathrm{~min}$. Este procedimento de lavagem foi realizado por mais 2 vezes com etanol $70 \%$ gelado e, por último, com $1 \mathrm{~mL}$ de etanol absoluto gelado. O DNA foi, então, secado por centrifugação a vácuo e ressuspendido em $50 \mu \mathrm{L}$ de tampão TE (10 mM Tris- $\mathrm{HCl}, \mathrm{pH}$ 8,0; 0,1 mM EDTA, pH 8,0).

3.2.3c Análise do polimorfismo $(\mathrm{CA})_{n}$ do gene IGF1 com o software GeneScan

Uma região de $200 \mathrm{pb}$ contendo o polimorfismo $(\mathrm{CA})_{\mathrm{n}}$ da região promotora do gene IGF1 (737/738) foi amplificada pela reação de polimerização em cadeia (PCR), conforme protocolo descrito por Arends et al. [106]. A reação foi realizada num volume final de $25 \mu \mathrm{L}$, contendo $50 \mathrm{ng}$ de DNA genômico, $1 \mu \mathrm{L}$ de tampão, 250 uM de dNTP, 2,2 nmol de $\mathrm{MgCl}$, 0,5 nmol de primers IGF1 sense: 5' ACCACTCTGGGAGAAGGGTA 3' e IGF1 anti-sense: 5' GCTAGCCAGCTGGTGTTATT 3', este último marcado com o fluorocromo FAM, e 0,4 U de Taq DNA polimerase (Invitrogen $®$ ). As condições de reação foram $94^{\circ} \mathrm{C}$ por 10 minutos; 35 ciclos constituídos de $94^{\circ} \mathrm{C}$ por 30 segundos, $55^{\circ} \mathrm{C}$ por 30 segundos e $72^{\circ} \mathrm{C}$ por 30 segundos, com extensão final de 10 minutos a $72^{\circ} \mathrm{C}$, em termociclador automático GeneAmp PCR Instrument System 9600 (Perkin-Elmer/Cetus, Norwalk, CT, USA). Todas as reações foram acompanhadas de um controle negativo.

Em seguida, $24 \mu \mathrm{L}$ de formamida deionizada e $1 \mu \mathrm{L}$ do padrão de peso molecular Rox 500 (Applied Biosystem ${ }^{\circledR}$ ) foram adicionados a $2 \mu \mathrm{L}$ do 
produto de amplificação. Essa mistura foi desnaturada a $94^{\circ} \mathrm{C}$ por 4 minutos e resfriada em gelo por 5 minutos. As amostras foram submetidas à eletroforese capilar em seqüenciador automático ABI 310 (Applied Biosystem ${ }^{\circledR}$ ) para subseqüente análise dos fragmentos por meio do software GeneScan.

3.2.3d Análise do VNTR do gene da insulina (VNTR INS) utilizando PCR e digestão enzimática

O polimorfismo INS-23 A/T, presente na região promotora do gene da insulina, está em desequilíbrio de ligação com as classes I e III do VNTR INS. A base adenina $(A)$ indica a presença do alelo classe I e a base timina (T) a presença do alelo classe III [119]. Uma região de 360 pb contendo esse polimorfismo foi amplificada, utilizando-se $200 \mathrm{ng}$ de DNA genômico, $5 \mu \mathrm{L}$ do tampão 10x da Taq DNA polimerase (Promega $\left.{ }^{\circledR}\right), 6,7 \mathrm{mM}$ de $\mathrm{MgCl}$, 1,5 mM de dNTP, $200 \mathrm{ng}$ de primers específicos VNTR INS-sense 5' AGCAGGTCTGTTCCAAGG $\quad 3^{\prime}$ e $\quad$ VNTR INS-antisense CTTGGGTGTGTAGAAGAAGC $\quad 3^{\prime}$ e $2,5 \quad U$ da Taq DNA polimerase (Promega ${ }^{\circ}$ ), num volume final de $50 \mu \mathrm{L}$ de reação. As condições de reação foram $96^{\circ} \mathrm{C}$ por 12 minutos; 35 ciclos constituídos de $94^{\circ} \mathrm{C}$ por 1 minuto, $54^{\circ} \mathrm{C}$ por 1 minuto e $72^{\circ} \mathrm{C}$ por 45 segundos; com 10 minutos a $72^{\circ} \mathrm{C}$ de extensão final. As amostras foram amplificadas num termociclador automático GeneAmp PCR Instrument System 9600 (Perkin-Elmer/Cetus, Norwalk, CT, USA) e todas as amplificações foram acompanhadas de um controle negativo.

O produto da PCR foi digerido com a enzima de restrição Hph1 (New 
England Biolabs $\left.{ }^{\circledR}\right)$, de acordo com as instruções do fabricante [119] e submetido à eletroforese em gel de agarose $3 \%$. Na presença da base timina, a enzima corta essa região em dois fragmentos: 231 pb, 129 pb, e na presença da base adenina em 3 fragmentos: 191 pb, 40 pb e 129 pb (figura $3)$.

O alelo VNTR classe II não foi estudado devido a dificuldades metodológicas.

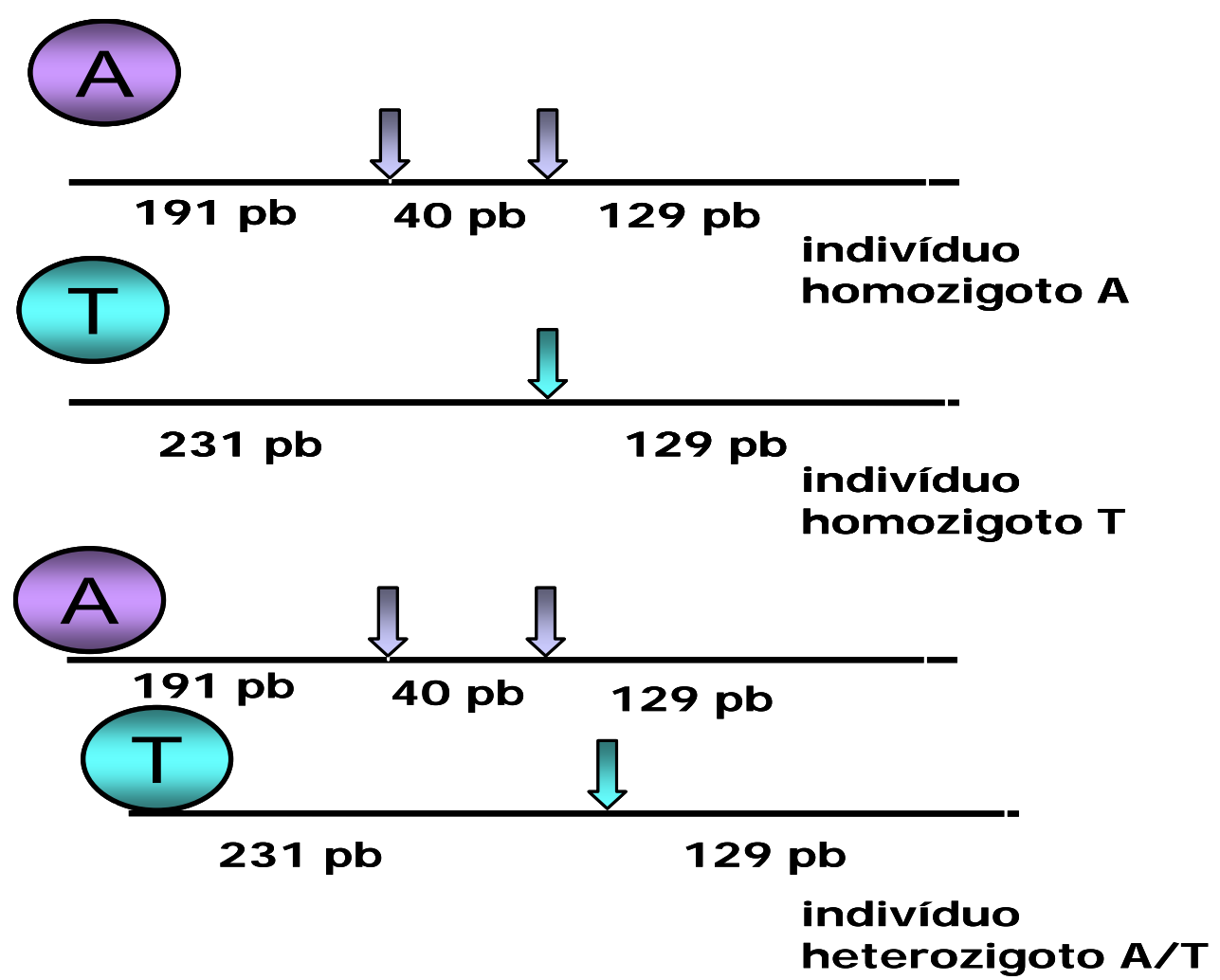

Figura 3 - Representação esquemática da digestão da região INS-23 A/T com enzima de restrição Hph1. Em indivíduos homozigoto A e homozigoto $\mathrm{T}$, serão observados fragmentos de 40 pb, 129 pb e 191 pb, e fragmentos de $129 \mathrm{pb}$ e $231 \mathrm{pb}$, respectivamente. Em indivíduos heterozigotos para o polimorfismo, todos os fragmentos, 40 pb, 129 pb, 191 pb e 231 pb, serão observados. 
3.2.3e Análise da região promotora P4 do gene IGF2 por seqüenciamento automático

Um fragmento de 755 pb contendo a região promotora P4 foi amplificado para o estudo do gene IGF2. Na reação de PCR, foram utilizados 200 ng do DNA genômico, $5 \mu \mathrm{L}$ do tampão 10x da Taq DNA polimerase (Promega $®$ ), 1,0 mM de dNTP, 200 ng de primers específicos IGF2-P4f1-sense 5'GAGACCGCGAGAGGAAGAC 3' e IGF2-P4r1-antisense 5' CAGgGgCAGAgGAAAGAG 3' e 0,5 $\mu \mathrm{L}$ da Taq DNA polimerase (Promega ${ }^{\circledR}$ ) num volume final de $50 \mu \mathrm{L}$. Os ciclos foram realizados em termociclador automático GeneAmp PCR Instrument System 9600 (PerkinElmer/Cetus, Norwalk, CT, USA), utilizando o seguinte programa de amplificação:desnaturação inicial a $94^{\circ} \mathrm{C}$ por 10 minutos; 35 ciclos constituídos de desnaturação a $94^{\circ} \mathrm{C}$ por 30 segundos, $60^{\circ} \mathrm{C}$ por 30 segundos e $72^{\circ} \mathrm{C}$ por 30 segundos; 10 minutos a $72^{\circ} \mathrm{C}$ de extensão final. Todas as amplificações foram acompanhadas de um controle negativo.

Os produtos da PCR foram submetidos a um pré-tratamento enzimático com a combinação das enzimas fosfatase alcalina de camarão

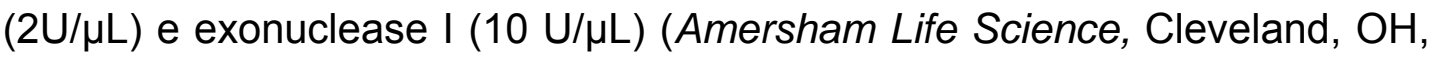
USA). Para a reação de seqüenciamento, foram misturados 1-2 $\mu \mathrm{L}$ de PCR purificado, 1,0 $\mu \mathrm{L}$ de primer (IGF2-P4f1 ou IGF2-P4r1 5 pmol), 2,0 $\mu \mathrm{L}$ de BIG DYE TERMINATOR v 3.1 CYCLE SEQUENCING KIT (ABI PRISM) e água desionizada estéril para um volume final de $10 \mu \mathrm{L}$. A reação foi levada a um termociclador por $96^{\circ} \mathrm{C} / 2 \mathrm{~min}$, seguindo-se 35 ciclos: $96^{\circ} \mathrm{C} / 30 \mathrm{~s}, 58^{\circ} \mathrm{C} / 20 \mathrm{~s}$ e $60^{\circ} \mathrm{C} / 4$ min. Para completar a leitura do fragmento, reações de seqüenciamento foram realizadas utilizando um primer interno IGF2-P4r2 
antisense 5' CACTCCAGCCTGAGGCA 3'.

Ao término do tempo de reação, o produto foi precipitado adicionandose $80 \mu \mathrm{L}$ de isopropanol $75 \%$ (preparado antes do uso) e incubando-se no escuro por 15 minutos à temperatura ambiente. O material foi centrifugado a 13.000 rpm por 30 minutos e o sobrenadante foi descartado. Ao tubo, foram adicionados $150 \mu \mathrm{L}$ de etanol $70 \%$ gelado, e centrifugado à mesma velocidade por mais 15 minutos. O etanol foi completamente descartado invertendo-se o tubo sobre papel toalha e deixado secar sobre a bancada ao abrigo da luz. A reação foi, então, ressuspendida em $3 \mu \mathrm{L}$ de solução 2:5 dextran:formamida e submetida à eletroforese em seqüenciador automático ABI 3100 Genetic Analyser.

\subsection{3f Extração de RNAm de linfócitos}

O RNA total de dois pacientes foi extraído a partir de $15 \mathrm{~mL}$ de sangue periférico utilizando-se o método do Trizol reagente, conforme as instruções do fabricante (Invitrogen, Carlsbad, CA, EUA). A integridade do RNA foi analisada em gel de agarose $1 \%$, e a concentração das amostras foi quantificada em espectrofotômetro. O DNA complementar (cDNA) foi sintetizado por transcrição reversa, utilizando o produto comercial High Capacity (Applied Biosystems, Forster City, CA, EUA) para ser empregado na amplificação por PCR em tempo real. 
3.2.3g Análise da expressão gênica do IGF2 pela técnica de PCR em tempo real

A quantificação relativa do cDNA IGF2 foi feita pelo método de PCR em tempo real utilizando a tecnologia 5' nuclease do sistema Taqman (Applied Biosystems, Foster City, CA). Para a amplificação e detecção do gene IGF2 foram utilizados oligonucleotídeos iniciadores e sondas comercialmente disponíveis (Assay ID $\underline{\text { Hs01005963 m1) }}$ (Assay on Demand Applied Biosystems, Foster city, CA, EUA). Uma vez que tal quantificação baseia-se na freqüência relativa dos transcritos do gene alvo em comparação com um gene de expressão constitutiva, esse sistema utiliza o gene da ß-actina como controle endógeno na normalização dos dados (Assay ID 4356315E).

As reações foram preparadas em triplicata, em um volume final de 25 uL, contendo 12,5 uL de TaqMan® Universal PCR Master Mix 2X (Applied Biosystems, Foster City, CA), 1,25 uL de cada assay (primers e sonda),20 X (Applied Biosystems, Foster City, CA ), 1,5 uL de cDNA e água milliQ a completar.

A detecção foi realizada na plataforma ABI PRISM 7000 (Applied Biosystems, Foster City, CA) com o seguinte protocolo de ciclagem: um ciclo de $50^{\circ} \mathrm{C}$ durante 2 minutos; um ciclo de $95^{\circ} \mathrm{C}$ durante 10 minutos; 50 ciclos de $95^{\circ} \mathrm{C}$ durante 15 segundos e $60^{\circ} \mathrm{C}$ durante 1 minuto. A validação desse método foi realizada pela construção de curvas de amplificação com concentrações progressivamente maiores de cDNA, a fim de se avaliar a especificidade dos primers, e se a eficiência de amplificação dos genes alvos e endógeno são comparáveis. 


\subsubsection{Análise estatística}

Como as crianças foram provenientes de três centros médicos de características muito diferentes, no que se refere à seleção dos pacientes, não foi possível considerar as crianças como um grupo único de pacientes. Para possibilitar a análise, buscando fatores identificadores ou associados ao crescimento pré e pós-natal, foi necessária uma correção dos dados pelo centro de origem, e uma análise de forma crítica na tentativa de identificar os fatores interferentes. Inicialmente, as análises foram realizadas, independentemente, para cada centro. Os dados categóricos (contagens) foram analisados com freqüência e percentual das ocorrências para os pacientes através de tabelas de contingências e da realização do teste Quiquadrado. Os dados contínuos (medidas) foram avaliados com comparação de médias por teste $T$, ou análise de variância (ANOVA) quando a variável estudada apresentava dados com distribuição normal ou comparação das medianas quando a distribuição dos dados era desviada (não normal), através do teste não paramétrico de Kruskal-Wallis.

Com o intuito de verificar a correlação entre as variáveis dependentes e independentes, foi realizada análise de regressão logística (não linear) para as variáveis dependentes binárias, e análise de regressão linear para as variáveis dependentes numéricas. A análise de correlação de Spearman foi utilizada para a seleção das variáveis independentes com significância de $p<0,20$

Em todas essas análises, foi utilizado o programa SPSS (Statistical Package fo Social Sciences), versão 13.0, para obtenção dos resultados, e 
foi considerado estatisticamente significante $o p<0,05$ para todas as análises. 
$\underline{\text { Resultados }}$ 
4.1. Avaliação clínica e laboratorial

A avaliação clínica foi realizada somente nos 142 indivíduos nascidos PIG com $(n=66)$ e sem $(n=76) R E$, e o estudo comparativo com o grupo controle não foi realizado. Sete dos meninos nascidos PIG (5\%) apresentavam hipospádia, cinco deles com RE e dois sem RE, e cinco outros indivíduos apresentavam síndrome de Silver Russell, três meninos e duas meninas, todos sem RE. A idade cronológica no momento da avaliação da presença ou ausência de RE, foi de 2 a 17 anos de idade e, na coleta dos exames laboratoriais, foi de 1,71 a 19 anos de idade. As variáveis antropométricas avaliadas estão descritas na tabela 3.

Tabela 3: Avaliação clínica dos indivíduos nascidos PIG.

\begin{tabular}{|c|c|c|c|}
\hline \multicolumn{4}{|c|}{ Indivíduos Nascidos PIG (n=142) } \\
\hline & Com RE (n=66) & Sem RE $(n=76)$ & \\
\hline Variáveis & $\begin{array}{c}\text { Média } \pm \text { DP } \\
\text { (Mínimo-Máximo) }\end{array}$ & $\begin{array}{c}\text { Média } \pm \text { DP } \\
\text { (Mínimo-Máximo) }\end{array}$ & $P$ \\
\hline $\begin{array}{c}\text { IG } \\
\text { (Semanas) }\end{array}$ & $\begin{array}{c}34 \pm 3 \\
(25-42) \\
\end{array}$ & $\begin{array}{c}37 \pm 3 \\
(25-40)\end{array}$ & NA \\
\hline Z-PN & $\begin{array}{l}-2,47 \pm 0,85 \\
(-4,15 \text { a } 1,0)\end{array}$ & $\begin{array}{c}-2,33 \pm 1,07 \\
(-4,70 \text { a } 2,70)\end{array}$ & $>0,05$ \\
\hline Z-CN & $\begin{array}{c}-3,45 \pm 1,16 \\
(-6,39 \text { a }-0,82)\end{array}$ & $\begin{array}{c}-3,42 \pm 1,28 \\
(-6,29 \text { a } 0,42)\end{array}$ & $>0,05$ \\
\hline Z-PC & $\begin{array}{c}-2,25 \pm 1,28 \\
(-4,77 \text { a } 1,07)\end{array}$ & $\begin{array}{c}-1,22 \pm 1,47 \\
(-4,36 \text { a } 1,81)\end{array}$ & $<0,05$ \\
\hline Z-Altura & $\begin{array}{c}-0,58 \pm 0,83 \\
(-1,96 \text { a } 2,71) \\
\end{array}$ & $\begin{array}{c}-3,14 \pm 1 \\
(-7,06 \text { a }-2,04)\end{array}$ & $<0,05$ \\
\hline Z-EA & $\begin{array}{c}-0,72 \pm 0,98 \\
(-2,21 \text { a } 1,62)\end{array}$ & $\begin{array}{l}-1,21 \pm 0,94 \\
(-3,0 \text { a } 1,62) \\
\end{array}$ & $<0,05$ \\
\hline Z-IMC & $\begin{array}{c}-0,29 \pm 1,71 \\
(-4,40 \text { a } 7,63)\end{array}$ & $\begin{array}{l}-1,16 \pm 1,56 \\
(-7,05 \text { a } 4,9)\end{array}$ & $<0,05$ \\
\hline Z-IGF1 & $\begin{array}{c}0,032 \pm 1,44 \\
(-2,31 \text { a } 6,03)\end{array}$ & $\begin{array}{c}-0,86 \pm 1,26 \\
(-2,62 \text { a } 2,89) \\
\end{array}$ & $<0,05$ \\
\hline Glicemia & $\begin{array}{c}81,25 \pm 10,22 \\
(40 \text { a } 98)\end{array}$ & $\begin{array}{c}81,61 \pm 7,11 \\
(60 \text { a } 93)\end{array}$ & $>0,05$ \\
\hline Insulina & $\begin{array}{c}6,32 \pm 5,35 \\
(1,7 \text { a } 25)\end{array}$ & $\begin{array}{l}4,45 \pm 0,70 \\
(1 \text { a } 15)\end{array}$ & $>0,05$ \\
\hline HOMA-IR & $\begin{array}{c}1,32 \pm 1,15 \\
(0,23 \text { a } 4,75)\end{array}$ & $\begin{array}{c}0,91 \pm 0,68 \\
(0,20 \text { a } 3,12)\end{array}$ & $>0,05$ \\
\hline
\end{tabular}

IG: idade gestacional; PN: peso ao nascimento; CN: comprimento ao nascimento; PC: perímetro cefálico; EA: estatura alvo; IMC: índice de massa corpórea; HOMAIR: índice para avaliação de resistência insulínica; NA: Não analisado; Em negrito: $p$ significante $<0,05$. 
Embora a idade gestacional tenha sido menor nas crianças com RE (Tabela 3), esses dados não foram analisados estatisticamente, porque a maioria das crianças com RE era proveniente do ambulatório de prematuros da Santa Casa de São Paulo, determinando um viés de seleção.

Observamos que as crianças PIG que tiveram RE apresentavam a média de Z-altura e Z-IMC, no exame clínico, significantemente maior que aquelas sem $\operatorname{RE}(p<0,05)$. Além disso, a média do Z-EA e o Z-altura do pai foram significantemente maiores no grupo de crianças que apresentaram RE $(p<0,05)$. Interessantemente, observamos que a média do Z-PC foi maior nas crianças sem RE (Tabela 3 ).

Verificamos que, nos indivíduos que apresentaram RE, a média do ZIGF1 sérico foi significantemente mais elevada que nos indivíduos que não apresentaram RE $(p<0,05)$. A média das concentrações séricas de insulina e do índice HOMA-IR foram maiores nas crianças que apresentaram RE, no entanto, essa diferença não foi estatisticamente significante (Tabela 3).

Em relação às condições maternas durante a gestação, observamos, pela análise de correlação, que a freqüência de tabagismo foi significantemente maior nas crianças que apresentaram recuperação estatural $(p<0,05)$. As freqüências de diabetes melito gestacional e diabetes prévio à gestação foram semelhantes nos grupos PIG com e sem RE (Tabela 4). As demais variáveis relacionadas às condições maternas (gemelaridade, DHEG e HAS) foram mais freqüentes nas crianças selecionadas junto ao ambulatório de prematuros da Santa Casa, de onde 
foi proveniente a maioria das crianças PIG com RE, devido a esse viés de seleção a análise estatística não foi realizada.

Tabela 4: Correlação das condições maternas na gestação com a presença de RE

\begin{tabular}{ccc}
\hline Condições maternas & Coeficiente de correlação & Significância $(p)$ \\
\hline Fumo & 0,169 & $\mathbf{0 , 0 4 5}$ \\
DMG & 0,090 & 0,285 \\
DM prévio & $-0,006$ & 0,944
\end{tabular}

DMG: diabetes melito gestacional; DM: diabetes melito; Em negrito: $p$ significante $<0,05$.

Pela análise de regressão logística, observamos que a maior probabilidade de ocorrer $\operatorname{RE}(99,93 \%)$ foi relacionada aos valores máximos das variáveis independentes Z-altura do pai, Z-IGF1. Observamos, pela análise de regressão linear, que não houve influência de nenhuma das variáveis clínicas analisadas no Z-altura e no Z-IGF1.

\subsection{Avaliação molecular}

Utilizando o teste do Qui-quadrado ou exato de Fisher observamos que não houve diferença estatisticamente significante na distribuição genotípica das variantes alélicas observadas descritas abaixo em relação ao esperado sob o Equilibrio de Hardy-Weinberg.

\subsubsection{Polimorfismo $(\mathrm{CA})_{\mathrm{n}}$ do gene IGF1}

Os 10 diferentes alelos do gene IGF1, identificados na população em estudo, variaram de 186 a 204 pb, de acordo com o número de repetições CA. Exemplificando: 19 repetições CA correspondem ao alelo com 192 pb; o de 20 repetições CA corresponde ao alelo com 194 pb, e assim por diante. 
Os alelos mais comuns apresentaram 190, 192, 194 e 196 pb, sendo que o mais freqüentemente observado foi o alelo contendo $192 \mathrm{pb}$. Considerando o alelo 192 pb como o nativo, classificamos os genótipos observados em relação à presença ou ausência desse alelo em homozigotos (192/192), heterozigotos $\left(192 /^{*}\right)$ e com a ausência do alelo $192\left({ }^{*} /{ }^{*}\right)$, cuja freqüência de distribuição na nossa população de indivíduos PIG foi de 28,9\%, 53,5\% e $17,6 \%$, respectivamente. As distribuições dos alelos e dos genótipos $(C A)_{n}$ mais freqüentes do gene IGF1, no grupo de indivíduos PIG e AIG (grupo controle), estão descritas nas tabelas 5 e 6 , respectivamente.

Tabela 5: Distribuição dos alelos mais freqüentes das repetições CA do gene IGF1 nos indivíduos PIG e AIG (grupo controle).

\begin{tabular}{|c|c|c|c|c|}
\hline \multirow[b]{2}{*}{ Alelos } & \multirow{2}{*}{$\begin{array}{c}\text { AlG* } \\
\text { Total } \% \\
(n=297)\end{array}$} & \multicolumn{3}{|c|}{ PIG* } \\
\hline & & $\begin{array}{l}\text { Total \% } \\
(n=142)\end{array}$ & $\begin{array}{c}\text { Com RE* } \\
\% \\
(n=66)\end{array}$ & $\begin{array}{c}\text { Sem } \mathrm{RE}^{*} \\
\% \\
(\mathrm{n}=76)\end{array}$ \\
\hline 190 & 10 & 12 & 17 & 7 \\
\hline 192 & 55 & 56 & 52 & 60 \\
\hline 194 & 16 & 18 & 15 & 21 \\
\hline 196 & 11 & 9 & 7 & 11 \\
\hline Outros & 8 & 5 & 9 & 1 \\
\hline
\end{tabular}

${ }^{*} p>0,05$ (PIG X AIG e PIG com RE X PIG sem RE)

Tabela 6: Distribuição genotípica das repetições CA do gene IGF1 nos indivíduos PIG e AIG (grupo controle).

\begin{tabular}{|c|c|c|c|c|}
\hline \multirow[b]{2}{*}{ Genótipos } & \multirow{2}{*}{$\begin{array}{c}\text { AlG* } \\
\text { Total \% } \\
(n=297)\end{array}$} & \multicolumn{3}{|c|}{ PIG* } \\
\hline & & $\begin{array}{l}\text { Total \% } \\
(n=142)\end{array}$ & $\begin{array}{c}\text { Com RE* } \\
\% \\
(n=66)\end{array}$ & $\begin{array}{c}\text { Sem } \mathrm{RE}^{*} \\
\% \\
(\mathrm{n}=76)\end{array}$ \\
\hline $190 / 192$ & 13 & 18 & 27 & 9 \\
\hline $192 / 192$ & 28 & 29 & 23 & 35 \\
\hline $192 / 194$ & 18 & 22 & 18 & 26 \\
\hline 192/196 & 14 & 10 & 7 & 13 \\
\hline $194 / 196$ & 4 & 6 & 4 & 8 \\
\hline Outros & 23 & 15 & 21 & 9 \\
\hline
\end{tabular}

${ }^{*} p>0,05$ (PIG X AIG e PIG com RE X PIG sem RE) 
As distribuições alélica e genotípica das repetições CA do gene IGF1 foram comparadas entre os grupos PIG e AIG, e entre as crianças PIG com e sem RE, utilizando o teste Qui-quadrado. Não foram observadas diferenças estatisticamente significantes dessas distribuições entre os indivíduos nascidos PIG e os controles AIG, e nem entre os indivíduos PIG com e sem RE. Da mesma forma, não encontramos associação desse polimorfismo com as variáveis clínicas e laboratoriais analisadas nesse estudo.

Dados desse polimorfismo foram publicado como Brief Report (anexo C).

4.2.2 Polimorfismo VNTR do gene da insulina

A distribuição e a freqüência dos alelos classe I e III do VNTR do gene da insulina e os genótipos homozigoto classe I (I/I), homozigoto Classe III (III/III) e heterozigoto (I/III) estão dispostos nas tabelas 7 e 8 . Observamos que não houve diferença estatisticamente significante da distribuição alélica e genotípica entre os grupos AIG e PIG, e nem entre os PIG com e sem RE. Da mesma forma, não encontramos associação desse polimorfismo com as variáveis clínicas e laboratoriais do estudo.

Tabela 7. Distribuição alélica do VNTR do gene da insulina entre os indivíduos PIG e AIG (grupo controle).

\begin{tabular}{|c|c|c|c|c|}
\hline \multirow[b]{2}{*}{ Alelos } & \multirow{2}{*}{$\begin{array}{c}\text { AlG* }^{*} \\
\text { Total } \% \\
(n=158)\end{array}$} & \multicolumn{3}{|c|}{ PIG* } \\
\hline & & $\begin{array}{l}\text { Total \% } \\
(n=142)\end{array}$ & $\begin{array}{c}\text { Com RE* } \\
\% \\
(n=66)\end{array}$ & $\begin{array}{c}\text { Sem RE* } \\
\% \\
(n=76)\end{array}$ \\
\hline Classe I & 59 & 52 & 54 & 51 \\
\hline Classe III & 41 & 48 & 46 & 49 \\
\hline
\end{tabular}
${ }^{*} p>0,05$ (PIG X AIG e PIG com RE X PIG sem RE) 
Tabela 8: Distribuição dos genótipos do VNTR do gene da insulina entre os indivíduos PIG e AIG (grupo controle).

\begin{tabular}{|c|c|c|c|c|}
\hline \multirow[b]{2}{*}{ Genótipos } & \multirow{2}{*}{$\begin{array}{c}\text { AlG* } \\
\text { Total \% } \\
(n=158)\end{array}$} & \multicolumn{3}{|c|}{ PIG* } \\
\hline & & $\begin{array}{l}\text { Total \% } \\
(n=142)\end{array}$ & $\begin{array}{c}\text { Com RE* } \\
\% \\
(n=66)\end{array}$ & $\begin{array}{c}\text { Sem RE* } \\
\% \\
(n=76)\end{array}$ \\
\hline $\mathrm{I} / \mathrm{I}$ & 34 & 32 & 34 & 30 \\
\hline III/III & 16 & 28 & 26 & 30 \\
\hline I/III & 50 & 40 & 40 & 40 \\
\hline
\end{tabular}

${ }^{*} p>0,05$ (PIG X AIG e PIG com RE X PIG sem RE)

\subsubsection{Região promotora P4 do gene IGF2}

Ao estudarmos a região promotora P4 do gene IGF2, identificamos um polimorfismo ainda não descrito na literatura, constituído por uma seqüência de repetições da base citosina (C) na posição -1982, nucleotídeos antes do sítio de início de transcrição do exon 2. De acordo com o número de repetições $C$, encontramos quatro alelos distintos: 9C, 10C, 11C e 12C. O alelo mais freqüente contém 11 repetições e foi considerado o alelo nativo (Tabela 9). Os genótipos foram classificados em relação à presença ou ausência do alelo $11 \mathrm{C}$ em: homozigoto (11C/11C); heterozigoto $\left(11 \mathrm{C} /{ }^{*}\right) \mathrm{e}$ para ausência do alelo $11 \mathrm{C}\left({ }^{*} /{ }^{*}\right)$,os quais apresentaram uma freqüência de $37 \%, 45 \%$ e 18\%, respectivamente. A freqüência das distribuições genotípicas dos alelos $C_{n}$ está descrita na tabela 10.

Tabela 9: Distribuição alélica das variantes polimórficas $C_{n}$ encontradas na região P4 do gene IGF2 entre os indivíduos PIG e AIG (grupo controle).

\begin{tabular}{|c|c|c|c|c|}
\hline \multirow[b]{2}{*}{ Alelos } & \multirow{2}{*}{$\begin{array}{c}\text { AIG* }^{*} \\
\text { Total } \% \\
(n=118)\end{array}$} & \multicolumn{3}{|c|}{ PIG* } \\
\hline & & $\begin{array}{l}\text { Total \% } \\
(n=142)\end{array}$ & $\begin{array}{c}\text { Com RE* } \\
\% \\
(n=66)\end{array}$ & $\begin{array}{c}\text { Sem RE* } \\
\% \\
(n=76)\end{array}$ \\
\hline $9 \mathrm{C}$ & 3 & 6 & 6 & 6 \\
\hline $10 \mathrm{C}$ & 28 & 26 & 23 & 29 \\
\hline $11 C$ & 64 & 61 & 60 & 62 \\
\hline $12 \mathrm{C}$ & 5 & 7 & 11 & 3 \\
\hline
\end{tabular}

${ }^{*} p>0,05$ (PIG X AIG e PIG com RE X PIG sem RE) 
Tabela 10: Distribuição dos genótipos das variantes $C_{n}$ encontradas na região P4 do gene IGF2 entre os indivíduos PIG e AIG (grupo controle).

\begin{tabular}{|c|c|c|c|c|}
\hline \multirow[b]{2}{*}{ Genótipos } & \multirow{2}{*}{$\begin{array}{c}\text { AlG* } \\
\text { Total } \% \\
(n=118)\end{array}$} & \multicolumn{3}{|c|}{ PIG* } \\
\hline & & $\begin{array}{l}\text { Total \% } \\
(n=142)\end{array}$ & $\begin{array}{c}\text { Com RE* } \\
\% \\
(n=66)\end{array}$ & $\begin{array}{c}\text { Sem RE* } \\
\% \\
(n=76)\end{array}$ \\
\hline $9 \mathrm{C} / 9 \mathrm{C}$ & 0 & 1,4 & 1,5 & 1,3 \\
\hline $9 \mathrm{C} / 10 \mathrm{C}$ & 1 & 0,7 & 0 & 1,4 \\
\hline $9 \mathrm{C} / 11 \mathrm{C}$ & 3 & 8 & 6 & 10 \\
\hline $9 \mathrm{C} / 12 \mathrm{C}$ & 0 & 2 & 3 & 1 \\
\hline $10 \mathrm{C} / 10 \mathrm{C}$ & 9 & 8 & 8 & 8 \\
\hline $10 \mathrm{C} / 11 \mathrm{C}$ & 36 & 27,2 & 18 & 36,3 \\
\hline $10 \mathrm{C} / 12 \mathrm{C}$ & 2 & 6 & 12 & 0 \\
\hline $11 \mathrm{C} / 11 \mathrm{C}$ & 41 & 38 & 41 & 35 \\
\hline $11 C / 12 C$ & 8 & 6 & 9 & 3 \\
\hline $11 \mathrm{C} / 11 \mathrm{C}-9 \mathrm{C} / \mathrm{T}$ & 0 & 2 & 0 & 4 \\
\hline $10 \mathrm{C} / 11 \mathrm{C}-9 \mathrm{C} / \mathrm{T}$ & 0 & 0,7 & 1,5 & 0 \\
\hline
\end{tabular}

As distribuições alélica e genotípica do polimorfismo $C_{n}$ foram comparadas entre os grupos PIG e AIG, e entre os indivíduos PIG com e sem RE, e não foram encontradas diferenças estatisticamente significantes entre esses grupos. Da mesma forma, não encontramos associação desse polimorfismo com as variáveis clínicas e laboratoriais analisadas nesse estudo.

Nessa mesma região, identificamos ainda uma troca C/T em heterozigose no nono nucleotídeo do alelo $11 \mathrm{C}$ em quatro meninas nascidas PIG, três delas homozigotas $11 \mathrm{C} / 11 \mathrm{C}$ e uma heterozigota 10C/11C. Três das crianças com o polimorfismo $C_{n}$, duas em homozigose e a criança heterozigota, não apresentaram RE (Figura 4). Essa variante alélica 9 C/T não foi identificada no grupo controle. 
A)

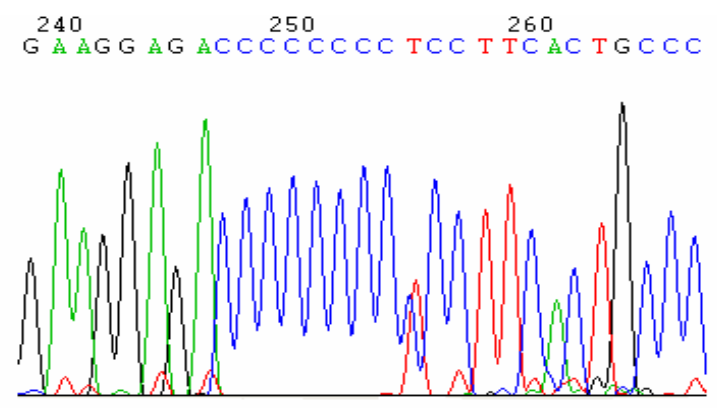

B)

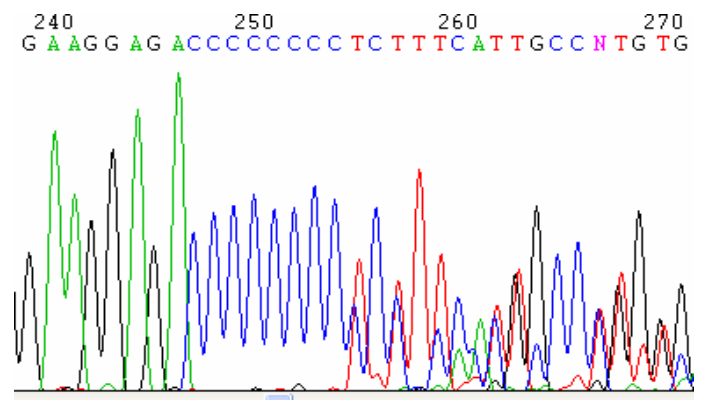

Figura 4: A) Polimorfismo 11C/11C-9C/T em homozigose; B) 10C/11C-9C/T em heterozigose na região promotora P4 do gene IGF2.

A segregação dessa variante foi realizada nos pais de duas crianças portadoras do alelo $9 \mathrm{C} / \mathrm{T}$, uma heterozigota 10C/11C (caso 1) e uma homozigota 11C/11C (caso 2). Observamos que as mães eram carreadoras da variação, e que apresentavam baixa estatura (Figura 5), no entanto, não eram nascidas pequenas para a idade gestacional. As concentrações séricas de IGF2 das mães e das crianças estavam dentro da normalidade para os valores de referência do método. 
Caso 1

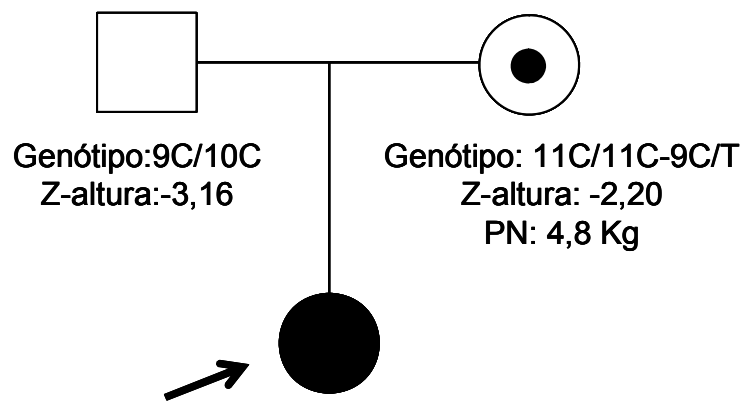

Genótipo: 10C-11C-9C/T Z-altura: $-2,04$

\section{Caso 2}

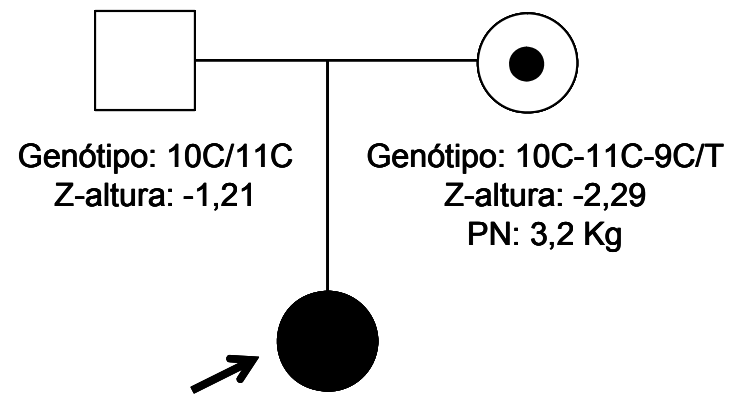

Genótipo: 11C-11C-9C/T Z-altura: $-2,61$

Figura 5: Heredograma de duas crianças PIG que apresentaram a variação alélica 9C/T. mulher portadora não PIG, probando PIG.

O estudo da expressão gênica do IGF2 pela técnica de PCR em tempo real foi realizado nessas duas crianças nascidas PIG portadoras da variante $9 \mathrm{C} / \mathrm{T}$ (caso 1 e 2). Os resultados dessa avaliação mostraram que esses exibiram uma expressão média de $2.1(\mathrm{DP}+/$ - 0.5) e de 0.74 (DP +/0,4), respectivamente. Esses valores representam o número de vezes que o gene se encontra expresso, em relação à média observada, em dois indivíduos do grupo controle, mostrando que a expressão do gene IGF2 não estava diminuída nesses pacientes. 
Discussão 


\subsection{Avaliação clínica}

Cerca de $3 \%$ das crianças nascem PIG, e dessas, $90 \%$ apresentam RE até os dois anos de vida. As crianças que não apresentam tal recuperação tendem a permanecer com baixa estatura na vida adulta [48]. $\mathrm{O}$ nosso estudo mostrou que os pais das crianças PIG sem RE, eram significantemente mais baixo que os pais das crianças com RE e ainda, o Zaltura dessas crianças era significantemente menor que o Z-EA desse grupo. Além disso, o Z-altura paterno dessas crianças foi menor que o das crianças com RE. Esses achados sugerem que os fatores genéticos que determinam a baixa estatura permanente em crianças nascidas PIG devem ser, principalmente, de origem paterna como já referido na literatura [148].

Ong et al. [148] mostraram que a recuperação estatural precoce, nos primeiros dois anos de vida, é um fator de risco para obesidade central na infância, e que pode contribuir, ainda, para as associações entre o RCIU e um maior risco de doenças cardiovasculares e diabetes melito tipo 2 na idade adulta. Corroborando com esses achados, observamos que o Z-IMC foi maior nas crianças com recuperação estatural, indicando que essas crianças devem ser acompanhadas até a idade adulta, com o objetivo de prevenir o aparecimento de obesidade e futuras co-morbidades nesses indivíduos.

A regulação da secreção de IGF1 e do crescimento pré-natal é realizada pelo eixo glicose-insulina-IGF1 [28]. Gluckman et al. [2] demonstraram que o tamanho ao nascimento apresenta correlação direta com as concentrações séricas de IGF1 no cordão umbilical, as quais, são diretamente influenciadas pelo estado nutricional do feto. Iñiguez et al. [149] 
observaram que as concentrações séricas de IGF1 em crianças nascidas PIG, durante o primeiro ano de vida, estão positivamente associadas com RE e podem refletir sua capacidade secretória de insulina. Portanto, maiores concentrações séricas de IGF1 em crianças PIG com RE espontânea podem constituir um indicador de relativa resistência à insulina e IGF1, e maior risco para o aparecimento de Diabetes melito tipo 2 na vida adulta. As concentrações séricas de IGF1, em nossa população foram significantemente mais altas nas crianças nascidas PIG com RE, no entanto as concentrações séricas de insulina foram semelhantes nos indivíduos PIG com e sem RE.

Nas últimas décadas, diversos estudos têm demonstrado a maior freqüência de resistência insulínica em crianças e adultos nascidos PIG [5963]. Soto et al. [31] evidenciaram maior resistência insulínica nas crianças nascidas PIG que apresentaram RE. Avaliamos a sensibilidade insulínica pelo índice HOMA-IR de indivíduos nascidos PIG com e sem RE e observamos que esse índice foi semelhante entre os dois grupos.

Nas crianças nascidas PIG a freqüência de hipospádia varia de 3,8 a $11 \%$, e nessas, há uma maior prevalência nos prematuros [37, 80]. De forma semelhante, em nossa casuística, a hipospádia foi observada em $5 \%$ dos indivíduos (7/142). Cinco desses indivíduos apresentaram recuperação estatural, sugerindo que os fatores genéticos e/ou ambientais que determinam o retardo do crescimento intra-uterino agem principalmente nas fases mais precoces da gestação, período em que ocorre a diferenciação da genitália externa. 
Dentre as causas maternas, o fumo é uma das causas evitáveis mais freqüentes de retardo de crescimento intra-uterino [150]. Recém-nascidos de mães fumantes, geralmente, têm menor peso, comprimento e perímetro cefálico ao nascimento $[151,152]$. Na avaliação das condições maternas durante a gestação, observamos que a incidência de tabagismo materno foi maior nas crianças PIG com RE, sugerindo que na vida pós-natal, fora do ambiente intra-uterino hostil, essas crianças passam a manifestar o seu potencial genético de crescimento.

\subsection{Análise do polimorfismo $\mathrm{CA}_{n}$ do gene IGF1}

O tamanho ao nascimento e a baixa estatura permanente em crianças nascidas PIG, provavelmente, apresentam etiologia poligênica. O gene IGF1 é um potencial candidato na etiologia do déficit de crescimento pré e pósnatal. Entretanto, a maioria dos estudos que analisaram a influência da presença ou ausência do alelo 192 (alelo nativo) das repetições $\mathrm{CA}_{n}$ (737/738) desse gene nas concentrações séricas de IGF1, crescimento intrauterino e pós-natal são controversos e foram realizados em crianças nascidas AIG ou adultos [102-104, 153].

Até o momento apenas dois estudos avaliaram o polimorfismo $\mathrm{CA}_{n}$ nos indivíduos nascidos PIG. No primeiro, Arends et al. [106] sugeriram que a presença do alelo 198 estaria associada com a baixa estatura em crianças PIG. No segundo, Johnston et al. [154] evidenciaram a associação de vários polimorfismos, inclusive o das repetições CA (737/738), com tamanho ao nascimento, recuperação estatural e concentrações de IGF1. Em nossa casuística, observamos uma baixa freqüência do alelo 198, e não foi 
observada influência do polimorfismo $(\mathrm{CA})_{\mathrm{n}}$ do gene IGF-1 no crescimento e nas concentrações séricas de IGF1, apesar dessas concentrações terem sido maiores nos indivíduos com RE. Dessa forma, concluímos que a variação genética nas repetições $(C A)_{n}$ não exerceu influência no crescimento pré e pós-natal, bem como nas concentrações séricas do IGF1 na população estudada.

\subsection{Análise do VNTR do gene da insulina}

Sabe-se que a insulina é um dos principais fatores endócrinos determinantes do crescimento fetal. Entretanto, a influência do polimorfismo VNTR INS no crescimento fetal de indivíduos nascidos AIG tem sido bastante controversa [58, 107, 115, 116, 118, 119]. Dunger et al. [107] associaram o VNTR INS classe III com um maior peso ao nascimento em crianças sem RE durante os primeiros dois anos de vida, e o VNTR classe I com um menor peso e comprimento ao nascimento em crianças sem RE. Contudo, essa relação não foi observada por outros autores [115, 116, 118]. Recentemente, foi sugerido que o alelo classe III não estaria associado com o tamanho ao nascimento, mas sim com a resistência à insulina nos adultos jovens nascidos PIG [120].

Em nosso estudo, não encontramos associação do VNTR INS com o tamanho ao nascimento, crescimento pós-natal ou com a presença de resistência à insulina. Todavia, a influência do VNTR INS no crescimento pré e pós-natal da população estudada só pode ser excluída após análise da origem parental dos alelos classe I e III, uma vez que o gene da insulina é metilado e apenas o alelo paterno é expresso. 
5.4 Análise da região promotora P4 do gene IGF2

É indiscutível o papel do IGF2 no crescimento fetal. A transcrição do gene humano que codifica essa proteína é regulada pela ativação de cinco promotores distintos (P0-P4), que atuam de maneira tecido-específica e tempo-desenvolvimento dependente, gerando diversas isoformas de RNA IGF2 [127]. Sabe-se que a região promotora P4 do gene IGF2 é uma das mais expressas no período pré-natal, e que camundongos knockout, para uma região promotora igualmente expressa na placenta, apresentam importante restrição de crescimento intra-uterino [94].

A análise in silico, utilizando o programa de predição TRANSFAC (http://www.gene-regulation.com/cgi-bin/pub/programs/alibaba2), mostrou 3 sítios de ligação para o fator de transcrição Sp1 nessa região. O fator de transcrição Sp1 foi previamente identificado como um importante ativador desse promotor na expressão do IGF2 em hepatócitos [155].

No entanto, pouco se conhece sobre os mecanismos moleculares que regulam essa expressão, não existindo, até o momento, nenhum estudo da região promotora P4 em humanos.

Identificamos um novo polimorfismo na região promotora P4 do gene IGF2, caracterizado pela presença de 9 a 12 repetições da base C. A freqüência alélica e genotípica dos alelos $9 \mathrm{C}, 10 \mathrm{C}, 11 \mathrm{C}$ e $12 \mathrm{C}$ foi semelhante nos indivíduos nascidos PIG e no grupo controle. Nessa mesma região, observamos, ainda, a troca $\mathrm{C}>\mathrm{T}$ em heterozigose no nono nucleotídeo, em quatro crianças nascidas PIG, sendo que tal alteração não foi encontrada nos indivíduos do grupo controle. 
O estudo de segregação familiar da variante alélica $9 \mathrm{C}>\mathrm{T}$ em duas crianças nascidas PIG mostrou que esse alelo foi herdado das mães que não haviam nascido PIG. No entanto, sabe-se que o IGF2 é um gene que sofre imprinting, no qual apenas o alelo paterno é expresso [156]. Além disso, a análise preliminar da expressão gênica do gene IGF2, utilizando RNAm extraídos de linfócitos de sangue periférico dessas crianças, mostrou que não há diminuição na expressão relativa desse gene quando comparada aos indivíduos controles. Dessa forma, não foram encontradas evidências da influência da região promotora P4 do gene IGF2 no crescimento intra-uterino em humanos. 
Conclusões 
1) A distribuição dos alelos classe I e III do VNTR INS e do polimorfismo $(\mathrm{CA})_{\mathrm{n}}$ do gene IGF-1 foi semelhante nos indivíduos nascidos AIG e PIG com e sem RE, bem como as freqüências alélicas e genotípicas.

2) Não observamos associação do VNTR INS com os valores de índice HOMA-IR, bem como do polimorfismo $(\mathrm{CA})_{\mathrm{n}}$ do gene IGF-1 com as concentrações séricas do IGF1.

3) Identificamos um novo polimorfismo de repetições $C$ na região promotora P4 do gene IGF2, e uma nova variante alélica $9 \mathrm{C}<\mathrm{T}$ nessa região em 4 crianças nascidas PIG.

4) Não identificamos influência dessas variantes alélicas no crescimento intra-uterino. 
Anexos 


\section{1 - Anexo A: Protocolo de Pesquisa}

Nome:

Registro:

Data nascimento: ........................... Sexo: fem ( ) masc. ( )

Hospital: HC ( ) Santa Casa ( ) Outro ( )

Endereço:

Telefone: $(. . . . . . .$.

Peso ao nascimento: ................... Comprimento ao nascimento:

Nascido a termo? Sim ( ) Não ( ) Idade gestacional:

Gestação gemelar? Não ( ) Sim ( ) Genitália ambígua? Sim ( ) Não ( )

Primogênito ? Sim ( ) Não ( )

Antecedentes patológicos:

Mãe: Peso: Altura:

Peso ao nasc.:

Pai: Altura:

Peso ao nascer:

Pré-termo ( )

TH do pcte

Intercorrências maternas durante a gestação:

( ) Uso de drogas ilícitas Quais?

( ) Etilismo ( ) Tabagismo

( ) Infecções

( ) Necessidade de tratamento para engravidar

( ) Doenças maternas

( ) Intercorrências na gravidez.

( ) Uso de hormônios / medicamentos na gravidez Nome.

Dose

Período.

História familiar de diabetes tipo 2 ?

( ) pai ( ) mãe ( ) tios ( ) avós ( ) Irmãos

\begin{tabular}{|c|c|c|c|}
\hline & Ao nascimento & 2 a 4 anos & na coleta de sg \\
\hline \multicolumn{4}{|l|}{ IC } \\
\hline \multicolumn{4}{|l|}{ Data } \\
\hline \multicolumn{4}{|l|}{ Peso } \\
\hline \multicolumn{4}{|l|}{ Estatura } \\
\hline Mamas & |--------------------------------- & |-------------------------------- & \\
\hline Pêlos pubianos & ---------------------------------- & ---------------------------------- & \\
\hline Testículos D/E & ---------------------------------- & ---------------------------------- & \\
\hline Pênis & 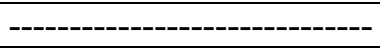 & 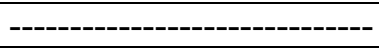 & \\
\hline Genitália & |--------------------------------- & |--------------------------------- & \\
\hline
\end{tabular}

Data ( I l )

Glicemia=

Insulina $=$

IGF1= 
7.2 - Anexo B: Termo de consentimento livre e esclarecido HOSPITAL DAS CLÍNICAS

da Faculdade de Medicina da Universidade de SÃo PaUlo CAIXA POSTAL, 8091 - SÃo PAULO - BRASIL

TERMO DE CONSENTIMENTO LIVRE E ESCLARECIDO

I - DADOS DE IDENTIFICAÇÃO DO SUJEITO DA PESQUISA OU RESPONSÁVEL LEGAL

1.NOME DO PACIENTE.

DOCUMENTO DE IDENTIDADE $\mathrm{N}^{\circ}$ : SEXO : .M F DATA NASCIMENTO: ........................

ENDEREÇO: $\mathrm{N}^{\mathrm{O}}$ APTO:

BAIRRO: CIDADE:

CEP: TELEFONE:DDD )

2.RESPONSÁVELLEGAL

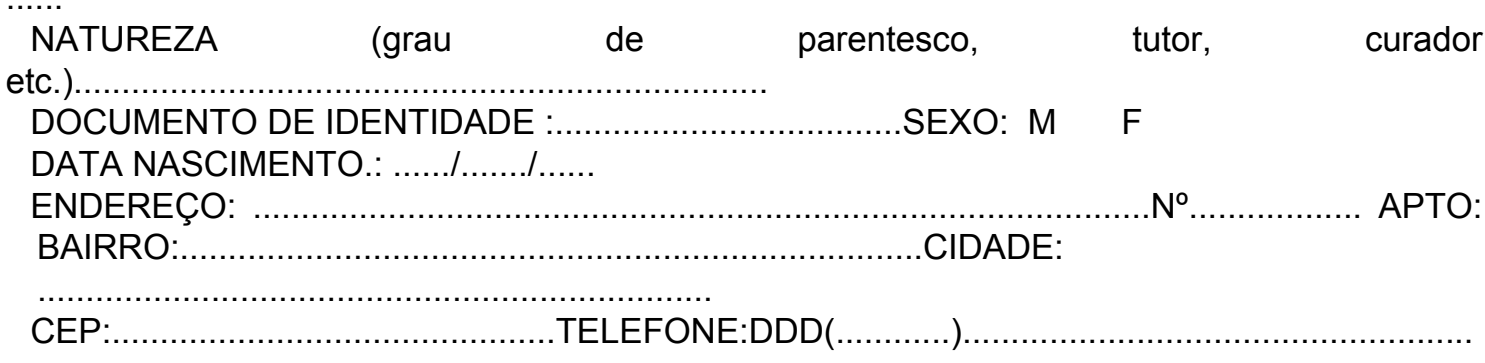
......

\section{II - DADOS SOBRE A PESQUISA CIENTÍFICA}

1. TÍTULO DO PROTOCOLO DE PESQUISA

ESTUDO DO VNTR DO GENE DA INSULINA, REGIÃO PROMOTORA P3 DO GENE DO IGF2 E REPETICCÕES CA DO GENE DO IGF1 EM INDIVÍDUOS NASCIDOS PEQUENOS PARA IDADE GESTACIONAL COM E SEM RECUPERAÇÃO ESTATURAL ASSOCIADA OU NÃO A HIPOSPÁDIA.

2. PESQUISADOR: Rocio Riatto Della Coletta

CARGO/FUNÇÃO: Doutoranda INSCRIÇÃO CONSELHO REGIONAL Nº113598

UNIDADE DO HCFMUSP: Disciplina de Endocrinologia, Unidade de Endocrinologia do Desenvolvimento

3. AVALIAÇÃO DO RISCO DA PESQUISA:

SEM RISCO

RISCO BAIXO estudo)

(probabilidade de que o indivíduo sofra algum dano como conseqüência imediata ou tardia do 


\section{III - REGISTRO DAS EXPLICAÇÕES DO PESQUISADOR AO PACIENTE OU SEU REPRESENTANTE LEGAL SOBRE A PESQUISA CONSIGNANDO:}

Estudaremos crianças que nasceram com peso e altura abaixo do normal que recuperaram ou não a altura nos primeiros 2 anos de vida, ou que tiveram defeitos nos genitais ao nascer com objetivo de saber porque algumas crianças que nasceram pequenas crescem normalmente nos primeiros anos de vida, enquanto outras continuam pequenas e ficam adultos baixos. Para isso, as crianças do estudo deverão colher um tubo pequeno de sangue para estudar o material genético=DNA (somente os genes relacionados com crescimento e diferenciação sexual). Além disso, nós vamos medir glicose (açúcar) do sangue, a insulina (hormônio que regula o açúcar no sangue) e o IGF1 (substância responsável pelo crescimento), porque alguns estudos mostram que essas crianças têm maior risco de ter diabetes na vida adulta. Ele vai sentir a picada da agulha como para fazer os exames de rotina e, eventualmente, pode ocorrer a formação de hematoma (mancha roxa na pele por extravasamento do sangue para fora do vaso sangüíneo) ou mais raramente flebite (inflamação da veia) no local da coleta de sangue. Poderemos encontrar com o estudo destes genes, um fator que possa identificar as crianças que necessitarão de hormônio de crescimento e de tratamento de prevenção do diabetes ainda na infância.

\section{IV - ESCLARECIMENTOS DADOS PELO PESQUISADOR SOBRE GARANTIAS DO SUJEITO DA PESQUISA CONSIGNANDO:}

1. acesso, a qualquer tempo, às informações sobre procedimentos, riscos e benefícios relacionados à pesquisa, inclusive para dirimir eventuais dúvidas. $\mathrm{O}$ paciente ou o responsável terá livre acesso aos dados colhidos e obtidos, assim como será informado sobre os riscos e os benefícios relacionados à pesquisa.

2. liberdade de retirar seu consentimento a qualquer momento e de deixar de participar do estudo, sem que isto traga prejuízo à continuidade da assistência. O paciente ou responsável terá plena liberdade de se retirar a qualquer momento do estudo sem qualquer prejuízo a sua pessoa. 
3. salvaguarda da confidencialidade, sigilo e privacidade. Todo o estudo será feito com total confidencialidade, sigilo e privacidade.

4. disponibilidade de assistência no HCFMUSP, por eventuais danos à saúde, decorrentes da pesquisa. O paciente terá total e plena assistência no HCFMUSP caso ajam quaisquer eventuais danos a sua saúde, decorrentes da pesquisa.

5. viabilidade de indenização por eventuais danos à saúde decorrentes da pesquisa.

\section{INFORMAÇÕES DE NOMES, ENDEREÇOS E TELEFONES DOS RESPONSÁVEIS PELO ACOMPANHAMENTO DA PESQUISA, PARA CONTATO EM CASO DE INTERCORRÊNCIAS CLÍNICAS E REAÇÕES ADVERSAS.}

Dra Rocio R. Della Coletta

R Dr . Enéas Carvalho Aguiar,155, prédio dos ambulatórios, $2^{\circ}$ andar, bloco 6.

Telefone: 30697512

VI - OBSERVAÇÕES COMPLEMENTARES

VII - CONSENTIMENTO PÓS-ESCLARECIDO

Declaro que, após convenientemente esclarecido pelo pesquisador e ter entendido o que me foi explicado, consinto em participar do presente Protocolo de Pesquisa

São Paulo, de de 200

Assinatura do sujeito da pesquisa ou responsável legal

Assinatura do pesquisador 
7.3 - Anexo C: Publicação

\title{
BRIEF REPORT
}

\section{Polymorphisms Identified in the Upstream Core Polyadenylation Signal of IGF1 Gene Exon 6 Do Not Cause Pre- and Postnatal Growth Impairment}

\author{
Debora C. Coutinho, Rocio R. D. Coletta, Elaine M. F. Costa, Paulo R. Pachi, \\ Margaret C. S. Boguszewski, Durval Damiani, Berenice B. Mendonca, Ivo J. P. Arnhold, and \\ Alexander A. L. Jorge \\ Unidade de Endocrinologia do Desenvolvimento (D.C.C., R.R.D.C., E.M.F.C., B.B.M., I.J.P.A., A.A.L.J.), Laboratorio de \\ Hormonios e Genetica Molecular LIM /42, Disciplina de Endocrinologia, Hospital das Clinicas da Faculdade de Medicina, \\ and Unidade de Endocrinologia Pediátrica (D.D.), Instituto da Criança, Hospital das Clínicas, Faculdade de Medicina, \\ Universidade de Sao Paulo, 05403-900 Sao Paulo, Brazil; Ambulatorio de Seguimento de Prematuros da Santa Casa de Sao \\ Paulo (P.R.P.), 01221-020 Sao Paulo, Brazil; and Unidade de Endocrinologia Pediatrica (M.C.S.B.), Departamento de \\ Pediatria, Hospital de Clinicas da Universidade Federal do Parana, 01221-020 Curitiba, Brazil
}

Background: Few children born small for gestational age (SGA) with IGF1 mutations have been reported. One of these patients presented a mutation at $3^{\prime}$ untranslated region (UTR) at exon 6 , probably affecting the polyadenylation process.

Objective: The objective of the study was to sequence the IGF1 gene of children born SGA

Patients and Methods: IGF1 (exons 1-6) was directly sequenced in 53 SGA children without catch-up growth. Allelic variant frequency of the identified IGF1 polymorphisms was assessed in a total of 145 SGA children and in 180 controls born with adequate weight and length and adult height SD score greater than -2 .

Results: No mutations were identified in the IGF1 coding regions in SGA children. In contrast, six allelic variants were identified in the upstream core polyadenylation signal located in IGF1 $33^{\prime}$ UTR at exon 6 . The frequency of the different allelic variants was similar in SGA children and controls. It is noteworthy that the same allelic variant, previously described as causing severe IGF1 deficiency, was also observed in homozygous $(n=4)$ and heterozygous state $(n=6)$ in normal height controls, corresponding to $4 \%$ of studied alleles. The three most frequently identified allelic variants of IGF1 $3^{\prime}$ UTR showed no effect on height SD score of adult controls as well as on birth characteristics in SGA children.

Conclusion: The polymorphisms identified in the upstream core polyadenylation signal at IGF1 exon 6 do not cause IGF1 deficiency as well as pre- and postnatal growth impairment, in contrast to previously reported data. (J Clin Endocrinol Metab 92: 4889-4892, 2007)
TGF1, OMIM 147440, IS A CRITICAL factor for pre- and 1 postnatal growth $(1,2)$. The major source of circulating IGF1 is the liver, but it is also ubiquitously produced in the body, with endocrine and paracrine action models (3). It is encoded by a single gene, the IGF1 (NM_000618.2), which comprises six exons, distributed along 84,647 bp in the long arm of chromosome 12 (12 q22-q23). There are two different classes of IGF1 mRNA, originated from different transcription start sites present in either exon 1 or 2 , which also codify part of the signal peptide (4). Additionally, IGF1 presents alternative splice sites that generate three major mRNA sizes of 1.1, 1.3, and 7.6 kb (5). The 1.1- and 7.6-kb IGF1 mRNAs comprise exons 1 or 2 plus exons 3,4 , and 6 , which share the same coding sequence and differ in terms of their $3^{\prime}$ un-

First Published Online September 25, 2007

Abbreviations: SDS, sD score; SGA, small for gestational age; UCPAS, upstream core polyadenylation signal; UTR, untranslated region.

JCEM is published monthly by The Endocrine Society (http://www. endo-society.org), the foremost professional society serving the endocrine community. translated region (UTR) due to alternative polyadenylation signal sequences at exon 6 (6). These two mRNAs produce IGF1A peptide (153 amino acids), the most abundant IGF1 isoform (5). On the other hand, the 1.3-kb IGF1 mRNA comprises exons 1 or 2 plus exons 3,4 , and 5, which generate IGF1B peptide (195 amino acids), a less abundant IGF1 isoform.

Three IGF1 mutations in homozygous state have been described to date: Woods et al. (7) described the deletion of IGF1 exons 4-5, whereas Bonapace et al. (8) reported a mutation located at the polyadenylation site at the $3^{\prime}$ UTR in exon 6 of the IGF1 gene in patients with IGF1 deficiency. Moreover, Walenkanp et al. (9) described an IGF1 missense mutation (V44M) that originates a biologically inactive IGF1 peptide. These patients share similar clinical features: intrauterine growth retardation followed by extremely short stature, mental retardation, microcephaly, and sensorineural deafness. These patients present high levels of basal and/or stimulated GH. Low or undetectable levels of IGF1 were observed in patients who carried disruptive IGF1 mutations, in contrast with high levels of IGF1 in those with the biologically inactive peptide. 
In 1990 Lajara et al. (10) screened for alterations in the IGF1 gene; however, their negative results were not conclusive due to technique limitation. Two subsequent studies systematically analyzed the coding region of the IGF1 gene in children with short stature: one analyzed exons 3 and 4 of the IGF1 gene in small for gestational age (SGA) children (11), whereas the other analyzed exons 1-5 in short children, regardless of birth weight and length (12). Both studies used the single strand conformation polymorphism mutation screening method and identified no mutations $(11,12)$. Single strand conformation polymorphism can present falsenegative results (13), which could have influenced the observed negative outcome. In the present study, we analyzed the IGF1 coding region by direct sequencing in children born SGA who did not present spontaneous catch-up growth. A highly polymorphic region in the exon 6 of IGF1 at $3^{\prime}$ UTR was identified in patients and controls, including one allelic variant previously described in an IGF1-deficient child; the relevance of these allelic variants on prenatal growth was investigated.

\section{Patients and Methods}

One hundred forty-five children born SGA that presented birth weight and/or length below $-2 \mathrm{sD}$ for gestational age (14) and uncomplicated neonatal period were selected. None of these children presented endocrine disorders, chronic diseases, skeletal alterations, or any syndrome except Silver-Russell syndrome (five cases). Fifty-three of the 145 SGA children that did not present catch-up growth, demonstrated by height sD score (SDS) less than -2 after 2 yr of age (15), were selected for the sequencing of IGF1 exon 1-6. The remaining 92 SGA children were included to assess the influence of allelic variants present in the exon 6 of IGF1 at $3^{\prime}$ UTR on prenatal growth.

One hundred eighty healthy adults born at term with adequate birth weight and length and height SDS greater than -2 comprised the control group.

\section{Molecular studies}

Genomic DNA was isolated from peripheral blood leukocytes. Exons $1-6$ of the IGF1 gene were amplified using intronic primers in the 53SGA children (primer sequences and amplification protocols will be provided on request). In the remaining $92 \mathrm{SGA}$ children and the adult controls, only exon 6 was amplified to assess the influence of allelic variants present in the $3^{\prime}$ UTR of IGF1 on prenatal growth. PCR products were directly sequenced with the dideoxy chain-termination method using a dye terminator kit and analyzed in an ABI Prism 3100 automated sequencer (Applied Biosystems, Foster City, CA).

\section{Statistical analysis}

Weight, length, and head circumference at birth were expressed as SDS for gestational age and sex (14), whereas height was expressed as SDS for age and sex (15). Differences between groups were analyzed by $t$ test or Mann-Whitney rank sum test for numerical variables and $\chi^{2}$ or Fisher exact test for nominal variables, as appropriate. Statistical significance was set at $P<0.05$. Statistical analyses were performed using the SIGMAstat statistical software package (Windows version 2.03; SPSS Inc., San Rafael, CA).

\section{Results}

No mutations in the coding region of IGF1 gene were identified in the 53 SGA children without spontaneous catch-up growth. It is notable that several allelic variants were identified in the exon 6 of IGF1 at 3'UTR in SGA children. These allelic variants are located $260 \mathrm{bp}$ downstream of TAG termination codon of IGF1 gene, in a region that is involved in the polyadenylation process, which is called the upstream core polyadenylation signal (UCPAS) (Fig. 1).

IGF1 exon 6 was sequenced in all remaining children born SGA as well as in controls. The six distinct allelic variants, numbered 1-6, in IGF1 UCPAS region were identified in comparison with the wild-type sequence (Fig. 1): variant 1 , an $\mathrm{A}>\mathrm{T}$ substitution in the first nucleotide comprising the AATATA polyadenylation signal motif; variant 2 , a $T>A$ substitution in the third nucleotide of AATATA motif; variant 3 , a deletion of the second nucleotide in AATATA motif; variant 4 , a substitution of $\mathrm{A}>\mathrm{T}$ in the nucleotide $1 \mathrm{bp}$ upstream of AATATA motif; variant 5, deletion of the third nucleotide in AATATA motif; and variant 6, a substitution of $\mathrm{A}>\mathrm{T}$ in the nucleotide $2 \mathrm{bp}$ upstream of AATATA motif together with allelic variant 1 .

The wild-type sequence was the most frequently observed allele in children born SGA as well as in controls (Table 1):
FIG. 1. Nucleotide sequence of the UCPAS located in exon 6 of the IGF 1 at $3^{\prime}$ UTR. Wild-type and six allelic variant sequences (numbered 1-6) are depicted. The natural and alternative polyadenylation signal motifs are underlined. Solid arrows indicate the nucleotide change(s) in each variant.

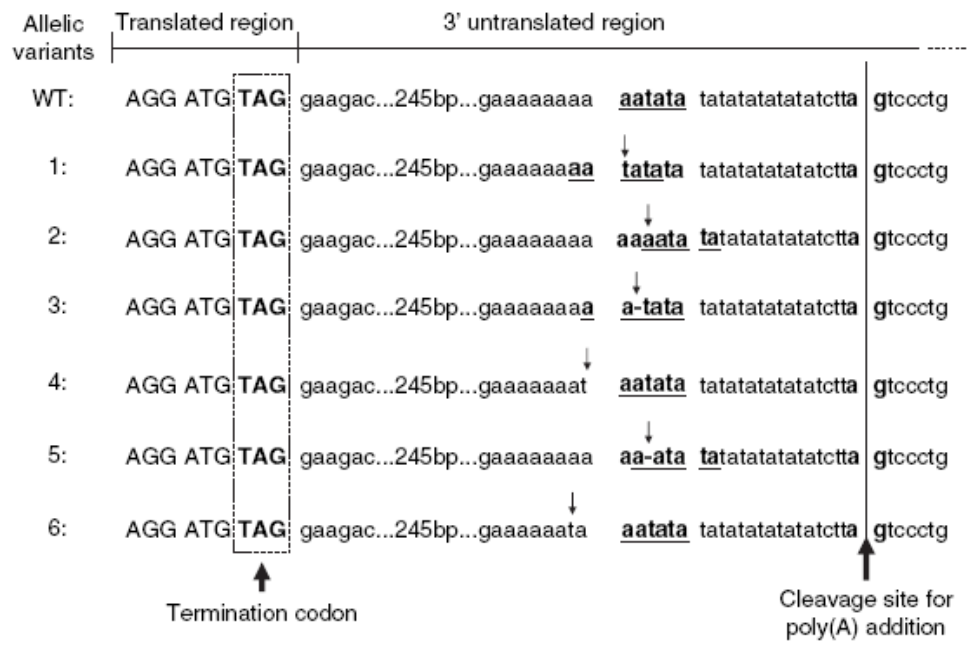


TABLE 1. Frequency of allelic variants observed in the UCPAS located in the exon 6 of $I G F 1$ at $3^{\prime} \mathrm{UTR}$

\begin{tabular}{lcc}
\hline \multicolumn{1}{c}{ Alleles } & $\begin{array}{c}\text { Controls, } \\
\mathrm{n}(\%)^{\alpha}\end{array}$ & $\begin{array}{c}\text { Children born SGA, } \\
\mathrm{n}(\%)\end{array}$ \\
\hline Wild-type variant & $278(77.2)$ & $226(77.9)$ \\
Allelic variant 1 & $51(14.2)$ & $42(14.5)$ \\
Allelic variant 2 & $14(3.9)$ & $6(2.1)$ \\
Allelic variant 3 & $11(3.1)$ & $11(3.8)$ \\
Allelic variant 4 & $5(1.4)$ & $2(0.7)$ \\
Allelic variant 5 & $0(0.0)$ & $2(0.7)$ \\
Allelic variant 6 & $1(0.3)$ & $1(0.3)$ \\
\hline
\end{tabular}

Data are shown as absolute numbers of alleles and percent.

${ }^{a}$ Controls were born adequate for gestational age and presented normal height at adult age.

it was found in homozygous state in $60 \%$ of SGA children and $63 \%$ of the control group. The frequencies of identified allelic variants were similar in the controls and in children born SGA (Table 1).

It is noteworthy that the allelic variant 2 , previously described by Bonapace et al. (8) as the cause of IGF1 deficiency in one SGA child, was also observed in homozygous $(n=4)$ and heterozygous state $(\mathrm{n}=6)$ in controls, corresponding to $3.9 \%$ of studied alleles. The heights SDS of the four adults homozygous for allelic variant 2 ranged from -0.1 to +2.4 .

The influence of the most frequent allelic variants on birth characteristics in children born SGA and on adult height in controls was investigated. Children homozygous for the wild-type allele or those carrying one or two copies of allelic variant 1,2 , or 3 presented similar gestational age, birth weight, length, and head circumference SDS (Table 2). Similarly, no effect of these allelic variants on adult height was observed: height SDS of $0.2 \pm 1.1$ for wild type $(n=112)$, $0.2 \pm 1.2$ for allelic variant 1 carriers $(n=48), 0.3 \pm 1.1$ for allelic variant 2 carriers $(\mathrm{n}=10), 0.2 \pm 1.2$ for allelic variant 3 carriers $(\mathrm{n}=11) ; P=0.9$.

\section{Discussion}

The substantial genetic contribution to interindividual variation of circulating IGF1 levels is well recognized (16). In addition, low circulating IGF1 levels were observed in children born SGA (1). However, there have been few reports of mutations in IGF1 gene explaining pre- and postnatal growth retardation (7-9), and few studies have investigated the association between growth and a limited number of polymorphisms in IGF1 noncoding region (17). In the present study, the IGF1 coding region was analyzed in a group of children born SGA without catch-up growth. None of these children had mutations or polymorphisms in the IGF1 coding region. Conversely, a very polymorphic region in the $3^{\prime}$
UTR sequence in IGF1 exon 6 was characterized. This region, located upstream of the polyadenylation addition site, comprehends an important region for the correct identification of the endonucleolytic cleavage of pre-mRNA and subsequent addition of poly(A) tail to the newly formed $3^{\prime}$ end (18).

The poly(A) tail is critical for the regulation of mRNA stability and translation (19). One of the polyadenylation signals is the highly conserved AAUAAA hexamer or a close variant thereof (termed UCPAS) located 10-30 nucleotides upstream of the cleavage site (20). The $\alpha$ - and $\beta$-thalassemia are examples of human diseases caused by mutations in UCPAS regions (18).

In 2003 Bonapace et al. (8) analyzed the IGF1 gene in one child born SGA presenting clinical and laboratory findings compatible with isolated IGF1 deficiency. The molecular study of the IGF1 gene in this patient disclosed a homozygous nucleotide substitution (AATATA > AAAATA) in the UCPAS located in IGF1 exon 6. The fact that this was the only allelic variant found in IGF1, and its absence in 100 unrelated healthy controls, led the authors to conclude that this mutation was responsible for the patient's phenotype $(8,18)$.

However, our molecular study of 145 SGA children and 180 adult controls identified several polymorphisms in IGF1 UCPAS, including the same allelic variant described by Bonapace et al. (8) identified in homozygous state in four controls from our cohort. It is noteworthy the AATATA > AAAATA change (allelic variant 2) yields an alternative AATATA motif $2 \mathrm{bp}$ downstream from the physiological UCPAS hexamer (Fig. 1). Similar upstream or downstream dislocation of the UCPAS hexamer occurs in the other described allelic variants. The fact that children and adults harboring these allelic variants do not present a distinct phenotype in comparison with those homozygous for the wild-type allele (Table 2) proposes that IGF1 UCPAS variants do not have a major influence on birth characteristics in children born SGA or on adult height of healthy individuals born adequate for gestational age. This finding suggests that AATATA > AAAATA change is not responsible for isolated IGF1 deficiency observed in the patient described by Bonapace et al. It is likely that a nonscreened mutation in the intronic or in the promoter region of IGF1 gene could be responsible for the phenotype observed in their patient.

In conclusion, IGF1 is a well-conserved gene, and mutations in IGF1 are rare in children born SGA. However, a highly polymorphic region located in the upstream core polyadenylation signal at IGF1 exon 6 has been identified for the first time in the present study. Our clinical and laboratory data demonstrate that these polymorphisms do not cause

TABLE 2. Clinical features at birth of children born SGA regarding the four most frequent genotypes in the UCPAS located in IGF1 exon 6

\begin{tabular}{|c|c|c|c|c|}
\hline \multirow{2}{*}{ Allelic variant } & \multirow{2}{*}{ Homozygous for wild type } & \multicolumn{3}{|c|}{ One or two alleles of allelic variants } \\
\hline & & 1 & 2 & 3 \\
\hline No. of individuals & 87 & 40 & 6 & 11 \\
\hline Gestational age, wk & $36 \pm 3.7$ & $36 \pm 3.2$ & $36 \pm 3.2$ & $34 \pm 3.5$ \\
\hline Length at birth SDS & $-3.3 \pm 1.3$ & $-3.3 \pm 1.3$ & $-2.5 \pm 0.7$ & $-3.2 \pm 1.1$ \\
\hline Weight at birth SD & $-2.5 \pm 1.0$ & $-2.3 \pm 0.6$ & $-2.4 \pm 0.5$ & $-2.0 \pm 1.8$ \\
\hline Head circumference SDS & $-2.0 \pm 1.5$ & $-1.6 \pm 1.4$ & $-1.8 \pm 1.7$ & $-2.3 \pm 0.8$ \\
\hline
\end{tabular}

Data are shown as mean $+\mathrm{SD}$. 
4892 J Clin Endocrinol Metab, December 2007, 92(12):4889-4892

IGF1 deficiency as well as pre- and postnatal growth impairment (8).

\section{Acknowledgments}

We thank Ms. Sonia Strong for helping with the English language.

Received July 25, 2007. Accepted September 19, 2007.

Address all correspondence and requests for reprints to: Alexande A. L. Jorge, Hospital das Clinicas, Laboratorio de Hormonios, Av D Eneas de Carvalho Aguiar 155 PAMB, 2 andar Bloco 6, 05403-900 São Paulo, Brazil. E-mail: alexj@usp.br

This work was supported by grants from Fundacao de Amparo a Pesquisa do Estado de Sao Paulo (05/04726-0) and Conselho Nacional de Desenvolvimento Cientifico e Tecnologico (142062/06-5, to D.C.C. 301246/95-5, to B.B.M.; 300938/06-3, to I.J.P.A.; 306000/04-0, to M.C.S.B., and 307951/06-5, to A.A.L.J.).

Disclosure Statement: The authors declare that they have no competing financial interests.

\section{References}

1. Murphy VE, Smith R, Giles WB, Clifton VL 2006 Endocrine regulation of human fetal growth: the role of the mother, placenta, and fetus. Endocr Rev 27:141-169

2. Jain S, Golde DW, Bailey R, Geffner ME 1998 Insulin-like growth factor-I resistance. Endocr Rev 19:625-646

3. Yakar S, Liu JL, Stannard B, Butler A, Accili D, Sauer B, LeRoith D 1999 Normal growth and development in the absence of hepatic insulin-like growth factor I. Proc Natl Acad Sci USA 96:7324-7329

4. Yang $H$, Adamo ML, Koval AP, McGuinness MC, Ben-Hur H, Yang $Y$, LeRoith D, Roberts Jr CT 1995 Alternative leader sequences in insulin-like growth factor I mRNAs modulate translational efficiency and encode multiple
signal peptides. Mol Endocrinol 9:1380-1395

5. Sussenbach JS, Steenbergh PH, Holthuizen P 1992 Structure and expression of the human insulin-like growth factor genes. Growth Regul 2:1-9

6. Jansen E, Steenbergh PH, van Schaik FM, Sussenbach JS 1992 The human IGF-I gene contains two cell type-specifically regulated promoters. Biochem Biophys Res Commun 187:1219-1226

7. Woods KA, Camacho-Hubner C, Savage MO, Clark AJ 1996 Intrauterine
Coutinho et al. • IGF1 Gene Polymorphisms and Growth Impairment

growth retardation and postnatal growth failure associated with deletion of the insulin-like growth factor I gene. N Engl J Med 335:1363-1367

8. Bonapace G, Concolino D, Formicola S, Strisciuglio P 2003 A novel mutation in a patient with insulin-like growth factor 1 (IGF1) deficiency. J Med Genet 40:913-917

9. Walenkamp MJ, Karperien M, Pereira AM, Hilhorst-Hofstee $Y$, van Doorn J, Chen JW, Mohan S, Denley A, Forbes B, van Duyvenvoorde HA, van Thie SW, Sluimers CA, Bax JJ, de Laat JA, Breuning MB, Romijn JA, Wit JM 2005 Homozygous and heterozygous expression of a novel insulin-like growth factor-I mutation. I Clin Endocrinol Metab 90:2855-2864

10. Lajara R, Galgani Jr JP, Dempsher DP, Bier DM, Rotwein P 1990 Low prevalence of insulin-like growth factor-1 gene mutations in human growt disorders. J Clin Endocrinol Metab 70:687-692

11. Johnston LB, Leger J, Savage MO, Clark AJ, Czernichow P 1999 The insulinlike growth factor-I (IGF-I) gene in individuals born small for gestational age (SGA). Clin Endocrinol (Oxf) 51:423-427

12. Obrepalska-Steplowska A, Kedzia A, Trojan J, Gozdzicka-Jozefiak A 2003 Analysis of coding and promoter sequences of the ICF-I gene in children with growth disorders presenting with normal level of growth hormone. J Pediat Endocrinol Metab 16:1267-1275

13. Hestekin CN, Barron AE 2006 The potential of electrophoretic mobility shift assays for clinical mutation detection. Electrophoresis 27:3805-3815

14. Usher R, McLean F 1969 Intrauterine growth of live-born Caucasian infant at sea level: stand ards obtained from measurements in 7 dimensions of infants born between 25 and 44 weeks of gestation. J Pediatr 74:901-910

15. Tanner JM, Whitehouse RH, Takaishi M 1966 Standards from birth to maturity for height, weight, height velocity, and weight velocity: British children, 1965. I. Arch Dis Child 41:454-471

16. Harrela M, Koistinen H, Kaprio J, Lehtovirta M, Tuomilehto J, Eriksson J, Toivanen L, Koskenvuo M, Leinonen P, Koistinen R, Seppala M 1996 Genetic and environmental components of interindividual variation in circulatin levels of IGF-I, IGF-II, IGFBP-1, and IGFBP-3. J Clin Invest 98:2612-2615

17. Johnston LB, Dahlgren J, Leger J, Gelander L, Savage MO, Czernichow P, Wikland KA, Clark AJ 2003 Association between insulin-like growth factor (IGF-I) polymorphisms, circulating IGF-I, and pre- and postnatal growth in two European small for gestational age populations. J Clin Endocrinol Metab 88:4805-4810 18. Chen JM, Ferec C,Cooper DN 2006 A systematic analysis of disease-associated
variants in the $3^{\prime}$ regulatory regions of human protein-coding genes I: general principles and overview. Hum Genet 120:1-21

19. Anderson JT 2005 RNA turnover: unexpected consequences of being tailed. Curr Biol 15:R635-R638

20. Zarudnaya MI, Kolomiets IM, Potyahaylo AL, Hovorun DM 2003 Downstream elements of mammalian pre-mRNA polyadenylation signals: primary, secondary and higher-order structures. Nucleic Acids Res 31:1375-1386

JCEM is published monthly by The Endocrine Society (http://www.endo-society.org), the foremost professional society serving the endocrine community. 
Referências 
1. Gluckman, P.D., Endocrine and nutritional regulation of prenatal growth. Acta Paediatr Suppl, 1997. 423: p. 153-7; discussion 158.

2. Gluckman, P.D., Clinical review 68: The endocrine regulation of fetal growth in late gestation: the role of insulin-like growth factors. J Clin Endocrinol Metab, 1995. 80(4): p. 1047-50.

3. Woods, K.A., et al., Intrauterine growth retardation and postnatal growth failure associated with deletion of the insulin-like growth factor I gene. N Engl J Med, 1996. 335(18): p. 1363-7.

4. Qiu, Q., et al., Role of pro-IGF-Il processing by proprotein convertase 4 in human placental development. Proc Natl Acad Sci U S A, 2005. 102(31): p. 11047-52.

5. Reiter EO, R., RG, Normal and aberrant growth., in Williams textbook of endocrinology. 1998: Philadelphia: WB Saunders. p. 1003-1114.

6. Baker, J., et al., Role of insulin-like growth factors in embryonic and postnatal growth. Cell, 1993. 75(1): p. 73-82.

7. Rosenzweig, S.A., What's new in the IGF-binding proteins? Growth Horm IGF Res, 2004. 14(5): p. 329-36.

8. Fowden, A.L., The insulin-like growth factors and feto-placental growth. Placenta, 2003. 24(8-9): p. 803-12.

9. Chard, T., Insulin-like growth factors and their binding proteins in normal and abnormal human fetal growth. Growth Regul, 1994. 4(3): p. 91-100.

10. Grahnen, A., et al., Pharmacokinetics of recombinant human insulinlike growth factor I given subcutaneously to healthy volunteers and to patients with growth hormone receptor deficiency. Acta Paediatr Suppl, 1993. 82 Suppl 391: p. 9-13; discussion 14.

11. Gluckman, P.D., et al., Studies of insulin-like growth factor -I and -Il by specific radioligand assays in umbilical cord blood. Clin Endocrinol (Oxf), 1983. 19(3): p. 405-13.

12. Bennett, A., et al., Levels of insulin-like growth factors I and II in human cord blood. J Clin Endocrinol Metab, 1983. 57(3): p. 609-12.

13. Luna, A.M., et al., Somatomedins in adolescence: a cross-sectional study of the effect of puberty on plasma insulin-like growth factor I and II levels. J Clin Endocrinol Metab, 1983. 57(2): p. 268-71.

14. Rudman, D., et al., Effects of human growth hormone in men over 60 years old. N Engl J Med, 1990. 323(1): p. 1-6.

15. Glasscock, G.F., et al., Pituitary control of growth in the neonatal rat: effects of neonatal hypophysectomy on somatic and organ growth, serum insulin-like growth factors (IGF)-I and -II levels, and expression of IGF binding proteins. Endocrinology, 1990. 127(4): p. 1792-803.

16. Donovan, S.M., et al., Ontogeny of serum insulin-like growth factor binding proteins in the rat. Endocrinology, 1989. 125(5): p. 2621-7.

17. Maffeis, C., et al., Insulin resistance and the persistence of obesity from childhood into adulthood. J Clin Endocrinol Metab, 2002. 87(1): p. 71-6.

18. Underwood, L.E., et al., Regulation of somatomedin-C/insulin-like growth factor I by nutrients. Horm Res, 1986. 24(2-3): p. 166-76. 
19. Hindmarsh, P., et al., Changes in serum insulin concentration during puberty and their relationship to growth hormone. Clin Endocrinol (Oxf), 1988. 28(4): p. 381-8.

20. Hindmarsh, P.C., et al., Relation between height velocity and fasting insulin concentrations. Arch Dis Child, 1988. 63(6): p. 665-6.

21. Godsland, I.F., The influence of female sex steroids on glucose metabolism and insulin action. J Intern Med Suppl, 1996. 738: p. 1-60.

22. Bloch, C.A., P. Clemons, and M.A. Sperling, Puberty decreases insulin sensitivity. J Pediatr, 1987. 110(3): p. 481-7.

23. Amiel, S.A., et al., Insulin resistance of puberty: a defect restricted to peripheral glucose metabolism. J Clin Endocrinol Metab, 1991. 72(2): p. 277-82.

24. Arslanian, S.A. and S.C. Kalhan, Correlations between fatty acid and glucose metabolism. Potential explanation of insulin resistance of puberty. Diabetes, 1994. 43(7): p. 908-14.

25. Milner, R.D. and D.J. Hill, Fetal growth control: the role of insulin and related peptides. Clin Endocrinol (Oxf), 1984. 21(4): p. 415-33.

26. Moses, A., Is insulin a growth factor? Insulin-like growth factors, 1991: p. 245-70.

27. Lemons, J.A., R. Ridenour, and E.N. Orsini, Congenital absence of the pancreas and intrauterine growth retardation. Pediatrics, 1979. 64(2): p. 255-7.

28. Gluckman, P.D. and J.E. Harding, Fetal growth retardation: underlying endocrine mechanisms and postnatal consequences. Acta Paediatr Suppl, 1997. 422: p. 69-72.

29. Jiang, Z.D., et al., Brainstem auditory-evoked responses to different rates of clicks in small-for-gestational age preterm infants at term. Acta Paediatr, 2004. 93(1): p. 76-81.

30. McCowan, L.M., J.E. Harding, and A.W. Stewart, Customized birthweight centiles predict SGA pregnancies with perinatal morbidity. Bjog, 2005. 112(8): p. 1026-33.

31. Soto, N., et al., Insulin sensitivity and secretion are related to catch-up growth in small-for-gestational-age infants at age 1 year: results from a prospective cohort. J Clin Endocrinol Metab, 2003. 88(8): p. 364550.

32. Alkalay, A.L., J.M. Graham, Jr., and J.J. Pomerance, Evaluation of neonates born with intrauterine growth retardation: review and practice guidelines. J Perinatol, 1998. 18(2): p. 142-51.

33. Lee, P.A., et al., International Small for Gestational Age Advisory Board consensus development conference statement: management of short children born small for gestational age, April 24-October 1, 2001. Pediatrics, 2003. 111(6 Pt 1): p. 1253-61.

34. Usher, R. and F. McLean, Intrauterine growth of live-born Caucasian infants at sea level: standards obtained from measurements in 7 dimensions of infants born between 25 and 44 weeks of gestation. J Pediatr, 1969. 74(6): p. 901-10.

35. Brenner, W.E., D.A. Edelman, and C.H. Hendricks, A standard of fetal growth for the United States of America. Am J Obstet Gynecol, 1976. 126(5): p. 555-64. 
36. Thomas, P., et al., A new look at intrauterine growth and the impact of race, altitude, and gender. Pediatrics, 2000. 106(2): p. E21.

37. Hussain, N., et al., Hypospadias and early gestation growth restriction in infants. Pediatrics, 2002. 109(3): p. 473-8.

38. Low, J.A., et al., Association of intrauterine fetal growth retardation and learning deficits at age 9 to 11 years. Am J Obstet Gynecol, 1992. 167(6): p. 1499-505.

39. Paz, I., et al., The cognitive outcome of full-term small for gestational age infants at late adolescence. Obstet Gynecol, 1995. 85(3): p. 4526.

40. Oyen, N., et al., Fetal growth retardation in sudden infant death syndrome (SIDS) babies and their siblings. Am J Epidemiol, 1995. 142(1): p. 84-90.

41. Taylor, D.J. and P.W. Howie, Fetal growth achievement and neurodevelopmental disability. Br J Obstet Gynaecol, 1989. 96(7): p. 789-94.

42. Osmond, C., et al., Early growth and death from cardiovascular disease in women. Bmj, 1993. 307(6918): p. 1519-24.

43. Ibanez, L., et al., Reduced ovulation rate in adolescent girls born small for gestational age. J Clin Endocrinol Metab, 2002. 87(7): p. 3391-3.

44. Hinchliffe, S.A., et al., The effect of intrauterine growth retardation on the development of renal nephrons. Br J Obstet Gynaecol, 1992. 99(4): p. 296-301.

45. Hales, C.N., et al., Fetal and infant growth and impaired glucose tolerance at age 64. Bmj, 1991. 303(6809): p. 1019-22.

46. Barker, D.J., et al., Relation of birth weight and childhood respiratory infection to adult lung function and death from chronic obstructive airways disease. Bmj, 1991. 303(6804): p. 671-5.

47. Wilton, P., et al., Growth hormone treatment induces a dosedependent catch-up growth in short children born small for gestational age: a summary of four clinical trials. Horm Res, 1997. 48 Suppl 1: p. 67-71.

48. Hokken-Koelega, A.C., et al., Children born small for gestational age: do they catch up? Pediatr Res, 1995. 38(2): p. 267-71.

49. Karlberg, J. and K. Albertsson-Wikland, Growth in full-term small-forgestational-age infants: from birth to final height. Pediatr Res, 1995. 38(5): p. 733-9.

50. Boguszewski, M., et al., Growth hormone treatment of short children born small-for-gestational-age: the Nordic Multicentre Trial. Acta Paediatr, 1998. 87(3): p. 257-63.

51. Carver, J.D., Nutrition for preterm infants after hospital discharge. Adv Pediatr, 2005. 52: p. 23-47.

52. Carrascosa, A., et al., Fetal growth regulation and intrauterine growth retardation. J Pediatr Endocrinol Metab, 2004. 17 Suppl 3: p. 435-43.

53. Ruzola, L., " Growth and development outcomes of the extremely preterm infant." J Pediatr, 2005. 81((suppl1)): p. 5101-5110.

54. Niklasson, A., et al., Growth in very preterm children: a longitudinal study. Pediatr Res, 2003. 54(6): p. 899-905. 
55. Francois, I. and F. de Zegher, Adrenarche and fetal growth. Pediatr Res, 1997. 41(3): p. 440-2.

56. Ghirri, P., et al., Adrenarche, pubertal development, age at menarche and final height of full-term, born small for gestational age (SGA) girls. Gynecol Endocrinol, 2001. 15(2): p. 91-7.

57. Tanner, J., Growth from birth to two: a critical review. Acta Med Auxol, 1994. 26: p. 7-45.

58. Lindsay, R.S., et al., The insulin gene variable number tandem repeat class I/III polymorphism is in linkage disequilibrium with birth weight but not Type 2 diabetes in the Pima population. Diabetes, 2003. 52(1): p. 187-93.

59. Phipps, K., et al., Fetal growth and impaired glucose tolerance in men and women. Diabetologia, 1993. 36(3): p. 225-8.

60. Veening, M.A., M.M. Van Weissenbruch, and H.A. Delemarre-Van De Waal, Glucose tolerance, insulin sensitivity, and insulin secretion in children born small for gestational age. J Clin Endocrinol Metab, 2002. 87(10): p. 4657-61.

61. Jaquet, D., et al., Insulin resistance early in adulthood in subjects born with intrauterine growth retardation. J Clin Endocrinol Metab, 2000. 85(4): p. 1401-6.

62. Hofman, P.L., et al., Insulin resistance in short children with intrauterine growth retardation. J Clin Endocrinol Metab, 1997. 82(2): p. 402-6.

63. Flanagan, D.E., et al., Fetal growth and the physiological control of glucose tolerance in adults: a minimal model analysis. Am J Physiol Endocrinol Metab, 2000. 278(4): p. E700-6.

64. Levy-Marchal, C. and P. Czernichow, Small for gestational age and the metabolic syndrome: which mechanism is suggested by epidemiological and clinical studies? Horm Res, 2006. 65 Suppl 3: p. 123-30.

65. Yajnik, C.S., et al., Adiposity and hyperinsulinemia in Indians are present at birth. J Clin Endocrinol Metab, 2002. 87(12): p. 5575-80.

66. Barker, D.J., et al., Type 2 (non-insulin-dependent) diabetes mellitus, hypertension and hyperlipidaemia (syndrome $X$ ): relation to reduced fetal growth. Diabetologia, 1993. 36(1): p. 62-7.

67. Jaquet, D., et al., Dynamic change in adiposity from fetal to postnatal life is involved in the metabolic syndrome associated with reduced fetal growth. Diabetologia, 2005. 48(5): p. 849-55.

68. Neel, J.V., Diabetes mellitus: a "thrifty" genotype rendered detrimental by "progress"? Am J Hum Genet, 1962. 14: p. 353-62.

69. Fowden, A.L., The role of insulin in prenatal growth. J Dev Physiol, 1989. 12(4): p. 173-82.

70. Economides, D.L., D. Crook, and K.H. Nicolaides, Hypertriglyceridemia and hypoxemia in small-for-gestational-age fetuses. Am J Obstet Gynecol, 1990. 162(2): p. 382-6.

71. Phillips, D.I., Insulin resistance as a programmed response to fetal undernutrition. Diabetologia, 1996. 39(9): p. 1119-22.

72. Baker, J., et al., Role of insulin-like growth factors in embryonic and postnatal growth. Cell, 1993. 75(1): p. 73-82. 
73. Wertheimer, E., et al., Homozygous deletion of the human insulin receptor gene results in leprechaunism. Nat Genet, 1993. 5(1): p. 713.

74. Morison, I.M., et al., Somatic overgrowth associated with overexpression of insulin-like growth factor II. Nat Med, 1996. 2(3): p. 311-6.

75. Raizis, A.M., M.R. Eccles, and A.E. Reeve, Structural analysis of the human insulin-like growth factor-II P3 promoter. Biochem J, 1993. 289 ( Pt 1): p. 133-9.

76. van Dijk, M.A., et al., Initial characterization of the four promoters of the human insulin-like growth factor II gene. Mol Cell Endocrinol, 1991. 81(1-3): p. 81-94.

77. Hattersley, A.T. and J.E. Tooke, The fetal insulin hypothesis: an alternative explanation of the association of low birthweight with diabetes and vascular disease. Lancet, 1999. 353(9166): p. 1789-92.

78. Rodriguez, S., et al., Haplotypic analyses of the IGF2-INS-TH gene cluster in relation to cardiovascular risk traits. Hum Mol Genet, 2004. 13(7): p. 715-25.

79. Gu, D., et al., Evidence of multiple causal sites affecting weight in the IGF2-INS-TH region of human chromosome 11. Hum Genet, 2002. 110(2): p. 173-81.

80. Gatti, J.M., et al., Increased incidence of hypospadias in small-forgestational age infants in a neonatal intensive-care unit. BJU Int, 2001. 87(6): p. 548-50.

81. Arnold, S.F., et al., Synergistic activation of estrogen receptor with combinations of environmental chemicals. Science, 1996. 272(5267): p. 1489-92.

82. Sharpe, R.M. and N.E. Skakkebaek, Are oestrogens involved in falling sperm counts and disorders of the male reproductive tract? Lancet, 1993. 341(8857): p. 1392-5.

83. Skakkebaek, N.E., E. Rajpert-De Meyts, and K.M. Main, Testicular dysgenesis syndrome: an increasingly common developmental disorder with environmental aspects. Hum Reprod, 2001. 16(5): p. 972-8.

84. Herber, S.M. and R.D. Milner, Growth hormone deficiency presenting under age 2 years. Arch Dis Child, 1984. 59(6): p. 557-60.

85. Ashton, W.S., et al., Testosterone increases insulin-like growth factor1 and insulin-like growth factor-binding protein. Ann Clin Lab Sci, 1995. 25(5): p. 381-8.

86. Elmlinger, M.W., et al., Decreased expression of IGF-II and its binding protein, IGF-binding protein-2, in genital skin fibroblasts of patients with complete androgen insensitivity syndrome compared with normally virilized males. J Clin Endocrinol Metab, 2001. 86(10): p. 4741-6.

87. Liu, J.P., et al., Mice carrying null mutations of the genes encoding insulin-like growth factor I (Igf-1) and type 1 IGF receptor (Igf1r). Cell, 1993. 75(1): p. 59-72. 
88. Al-Regaiey, K.A., et al., Long-lived growth hormone receptor knockout mice: interaction of reduced insulin-like growth factor i/insulin signaling and caloric restriction. Endocrinology, 2005. 146(2): p. 851-60.

89. Duville, B., Phenotipic alterations in insulin-deficient mutant mice. Proc Natl Acad Sci USA, 1997. 94: p. 5137-5140.

90. Silha, J.V. and L.J. Murphy, Insights from insulin-like growth factor binding protein transgenic mice. Endocrinology, 2002. 143(10): p. 3711-4.

91. Schneider, M.R., et al., Transgenic mouse models for studying the functions of insulin-like growth factor-binding proteins. Faseb J, 2000. 14(5): p. 629-40.

92. Ueki, I., et al., Inactivation of the acid labile subunit gene in mice results in mild retardation of postnatal growth despite profound disruptions in the circulating insulin-like growth factor system. Proc Natl Acad Sci U S A, 2000. 97(12): p. 6868-73.

93. Joshi, R.L., et al., Targeted disruption of the insulin receptor gene in the mouse results in neonatal lethality. Embo J, 1996. 15(7): p. 15427.

94. Constancia, M., et al., Placental-specific IGF-II is a major modulator of placental and fetal growth. Nature, 2002. 417(6892): p. 945-8.

95. DeChiara, T.M., E.J. Robertson, and A. Efstratiadis, Parental imprinting of the mouse insulin-like growth factor II gene. Cell, 1991. 64(4): p. 849-59.

96. Ogilvy-Stuart, A.L., et al., Hypoglycemia and resistance to ketoacidosis in a subject without functional insulin receptors. J Clin Endocrinol Metab, 2001. 86(7): p. 3319-26.

97. Bonapace, G., et al., A novel mutation in a patient with insulin-like growth factor 1 (IGF1) deficiency. J Med Genet, 2003. 40(12): p. 9137.

98. Walenkamp, M.J., et al., Homozygous and heterozygous expression of a novel insulin-like growth factor-I mutation. J Clin Endocrinol Metab, 2005. 90(5): p. 2855-64.

99. Gicquel, C., et al., Epimutation of the telomeric imprinting center region on chromosome 11p15 in Silver-Russell syndrome. Nat Genet, 2005. 37(9): p. 1003-7.

100. Wutz, A., O.W. Smrzka, and D.P. Barlow, Making sense of imprinting the mouse and human IGF2R loci. Novartis Found Symp, 1998. 214: p. 251-9; discussion 260-3.

101. Dunger, D.B., Genetics of Size at Birth, in Diabetes Care. 2007. p. S150-S155.

102. Rosen, C.J., et al., Association between serum insulin growth factor-I (IGF-I) and a simple sequence repeat in IGF-I gene: implications for genetic studies of bone mineral density. J Clin Endocrinol Metab, 1998. 83(7): p. 2286-90.

103. Vaessen, N., et al., A polymorphism in the gene for IGF-I: functional properties and risk for type 2 diabetes and myocardial infarction. Diabetes, 2001. 50(3): p. 637-42.

104. Frayling, T.M., et al., A putative functional polymorphism in the IGF-I gene: association studies with type 2 diabetes, adult height, glucose 
tolerance, and fetal growth in U.K. populations. Diabetes, 2002. 51(7): p. 2313-6.

105. Johnston, L.B., et al., The insulin-like growth factor-I (IGF-I) gene in individuals born small for gestational age (SGA). Clin Endocrinol (Oxf), 1999. 51(4): p. 423-7.

106. Arends, N., et al., Polymorphism in the IGF-I gene: clinical relevance for short children born small for gestational age (SGA). J Clin Endocrinol Metab, 2002. 87(6): p. 2720.

107. Dunger, D.B., et al., Association of the INS VNTR with size at birth. ALSPAC Study Team. Avon Longitudinal Study of Pregnancy and Childhood. Nat Genet, 1998. 19(1): p. 98-100.

108. Mclntyre, E.A. and M. Walker, Genetics of type 2 diabetes and insulin resistance: knowledge from human studies. Clin Endocrinol (Oxf), 2002. 57(3): p. 303-11.

109. Bell, G.I., M.J. Selby, and W.J. Rutter, The highly polymorphic region near the human insulin gene is composed of simple tandemly repeating sequences. Nature, 1982. 295(5844): p. 31-5.

110. Paquette, J., et al., The INS 5' variable number of tandem repeats is associated with IGF2 expression in humans. J Biol Chem, 1998. 273(23): p. 14158-64.

111. Bennett, S.T. and J.A. Todd, Human type 1 diabetes and the insulin gene: principles of mapping polygenes. Annu Rev Genet, 1996. 30: p. 343-70.

112. Vafiadis, P., et al., Imprinted and genotype-specific expression of genes at the IDDM2 locus in pancreas and leucocytes. J Autoimmun, 1996. 9(3): p. 397-403.

113. Bennett, S.T., et al., IDDM2-VNTR-encoded susceptibility to type 1 diabetes: dominant protection and parental transmission of alleles of the insulin gene-linked minisatellite locus. J Autoimmun, 1996. 9(3): p. 415-21.

114. Vafiadis, P., et al., Insulin expression in human thymus is modulated by INS VNTR alleles at the IDDM2 locus. Nat Genet, 1997. 15(3): p. 289-92.

115. Ong, K.K., et al., Maternal-fetal interactions and birth order influence insulin variable number of tandem repeats allele class associations with head size at birth and childhood weight gain. Diabetes, 2004. 53(4): p. 1128-33.

116. Ong, K.K., et al., The insulin gene VNTR, type 2 diabetes and birth weight. Nat Genet, 1999. 21(3): p. 262-3.

117. Ibanez, L., et al., Insulin gene variable number of tandem repeat genotype and the low birth weight, precocious pubarche, and hyperinsulinism sequence. J Clin Endocrinol Metab, 2001. 86(12): p. 5788-93.

118. Bennett, A.J., et al., Variation at the insulin gene VNTR (variable number tandem repeat) polymorphism and early growth: studies in a large Finnish birth cohort. Diabetes, 2004. 53(8): p. 2126-31.

119. Mitchell, S.M., et al., Lack of support for a role of the insulin gene variable number of tandem repeats minisatellite (INS-VNTR) locus in 
fetal growth or type 2 diabetes-related intermediate traits in United Kingdom populations. J Clin Endocrinol Metab, 2004. 89(1): p. 310-7.

120. Vu-Hong, T.A., et al., The INS VNTR locus does not associate with smallness for gestational age (SGA) but interacts with SGA to increase insulin resistance in young adults. J Clin Endocrinol Metab, 2006. 91(6): p. 2437-40.

121. Mook-Kanamori, D.O., et al., Insulin gene variable number of tandem repeats is not associated with weight from fetal life until infancy: the Generation R Study. Eur J Endocrinol, 2007. 157(6): p. 741-8.

122. Daughaday, W.H. and P. Rotwein, Insulin-like growth factors I and II. Peptide, messenger ribonucleic acid and gene structures, serum, and tissue concentrations. Endocr Rev, 1989. 10(1): p. 68-91.

123. Riderknecht, E., The amino acid sequence of human insulin-like growth factor I and its strutural homology with pro insulin. J Biol Chem, 1978. 253: p. 2769-2776.

124. Riderknecht, E., Primary struture of human insulin-like growth factor II. FEBS Lett, 1978. 89: p. 283-286.

125. Le Stunff, C., D. Fallin, and P. Bougneres, Paternal transmission of the very common class I INS VNTR alleles predisposes to childhood obesity. Nat Genet, 2001. 29(1): p. 96-9.

126. Rietveld, L.E., et al., Dual role for transcription factor AP-2 in the regulation of the major fetal promoter $P 3$ of the gene for human insulin-like growth factor II. Biochem J, 1999. 338 ( Pt 3): p. 799-806.

127. Monk, D., et al., Imprinting of IGF2 PO transcript and novel alternatively spliced INS-IGF2 isoforms show differences between mouse and human. Hum Mol Genet, 2006. 15(8): p. 1259-69.

128. Tricoli, J.V., et al., Enhanced levels of insulin-like growth factor messenger RNA in human colon carcinomas and liposarcomas. Cancer Res, 1986. 46(12 Pt 1): p. 6169-73.

129. Holthuizen, P., et al., Identification and initial characterization of a fourth leader exon and promoter of the human IGF-II gene. Biochim Biophys Acta, 1990. 1087(3): p. 341-3.

130. Mineo, R., et al., Promoter usage for insulin-like growth factor-ll in cancerous and benign human breast, prostate, and bladder tissues, and confirmation of a 10th exon. Biochem Biophys Res Commun, 2000. 268(3): p. 886-92.

131. Rietveld, L.E., P.E. Holthuizen, and J.S. Sussenbach, Identification of a key regulatory element for the basal activity of the human insulin-like growth factor II gene promoter P3. Biochem J, 1997. 327 ( Pt 3): p. 689-97.

132. Hyun, S.W., et al., Characterization of the $P 4$ promoter region of the human insulin-like growth factor II gene. FEBS Lett, 1993. 332(1-2): p. 153-8.

133. Gaunt, T.R., et al., Positive associations between single nucleotide polymorphisms in the IGF2 gene region and body mass index in adult males. Hum Mol Genet, 2001. 10(14): p. 1491-501.

134. O'Dell, S.D., et al., Apal polymorphism in insulin-like growth factor II (IGF2) gene and weight in middle-aged males. Int J Obes Relat Metab Disord, 1997. 21(9): p. 822-5. 
135. analyser, G., Birth length for gestational age. 2006, Usher and Mc Lean-1969: Canadian.

136. Analyser, G., Birth weight for gestational age. 2006, Usher and Mc Lean - 1969: Canadian.

137. Analyser, G., Height. 2006, United Kingdom -1990: United Kingdom.

138. Analyser, G., Head circumference at birth for gestational age. 2006, Usher and Mc Lean - 1969: Canadian.

139. Tanner, J.M., H. Goldstein, and R.H. Whitehouse, Standards for children's height at ages 2-9 years allowing for heights of parents. Arch Dis Child, 1970. 45(244): p. 755-62.

140. Trinder, P., Determination of glucose in blood using oxidase with an alternative oxygen acceptor. Ann Clin Biochem, 1969. 6: p. 24-27.

141. Hemmila, I., et al., Europium as a label in time-resolved immunofluorometric assays. Anal Biochem, 1984. 137(2): p. 335-43.

142. Soini, E. and H. Kojola, Time-resolved fluorometer for lanthanide chelates--a new generation of nonisotopic immunoassays. Clin Chem, 1983. 29(1): p. 65-8.

143. Matthews, D.R., et al., Homeostasis model assessment: insulin resistance and beta-cell function from fasting plasma glucose and insulin concentrations in man. Diabetologia, 1985. 28(7): p. 412-9.

144. Elmlinger, M.W., et al., Reference ranges for two automated chemiluminescent assays for serum insulin-like growth factor I (IGF-I) and IGF-binding protein 3 (IGFBP-3). Clin Chem Lab Med, 2004. 42(6): p. 654-64.

145. Miles, L.E. and C.N. Hales, Labelled antibodies and immunological assay systems. Nature, 1968. 219(5150): p. 186-9.

146. Miller, S.A., D.D. Dykes, and H.F. Polesky, A simple salting out procedure for extracting DNA from human nucleated cells. Nucleic Acids Res, 1988. 16(3): p. 1215.

147. Phillips, D.I., et al., Thinness at birth and insulin resistance in adult life. Diabetologia, 1994. 37(2): p. 150-4.

148. Ong, K.K., et al., Association between postnatal catch-up growth and obesity in childhood: prospective cohort study. Bmj, 2000. 320(7240): p. 967-71.

149. Iniguez, G., et al., Longitudinal changes in insulin-like growth factor-I, insulin sensitivity, and secretion from birth to age three years in smallfor-gestational-age children. J Clin Endocrinol Metab, 2006. 91(11): p. 4645-9.

150. Saenger, P., et al., Small for gestational age: short stature and beyond. Endocr Rev, 2007. 28(2): p. 219-51.

151. Cliver, S.P., et al., The effect of cigarette smoking on neonatal anthropometric measurements. Obstet Gynecol, 1995. 85(4): p. 62530.

152. Pringle, P.J., et al., The influence of cigarette smoking on antenatal growth, birth size, and the insulin-like growth factor axis. J Clin Endocrinol Metab, 2005. 90(5): p. 2556-62.

153. Vaessen, N., et al., Association between genetic variation in the gene for insulin-like growth factor-I and low birthweight. Lancet, 2002. 359(9311): p. 1036-7. 
154. Johnston, L.B., et al., Association between insulin-like growth factor I (IGF-I) polymorphisms, circulating IGF-I, and pre- and postnatal growth in two European small for gestational age populations. J Clin Endocrinol Metab, 2003. 88(10): p. 4805-10.

155. Scharf, J.G., F. Dombrowski, and G. Ramadori, The IGF axis and hepatocarcinogenesis. Mol Pathol, 2001. 54(3): p. 138-44.

156. Netchine, I., et al., 11p15 imprinting center region 1 loss of methylation is a common and specific cause of typical Russell-Silver syndrome: clinical scoring system and epigenetic-phenotypic correlations. J Clin Endocrinol Metab, 2007. 92(8): p. 3148-54. 